\title{
CEsifo \\ WORKING

\section{The Brexit as a Forerunner: Monetary Policy, Economic Order and Divergence Forces in the European Union}

Sebastian Müller, Gunther Schnabl 


\section{Impressum:}

CESifo Working Papers

ISSN 2364-1428 (electronic version)

Publisher and distributor: Munich Society for the Promotion of Economic Research - CESifo $\mathrm{GmbH}$

The international platform of Ludwigs-Maximilians University's Center for Economic Studies and the ifo Institute

Poschingerstr. 5, 81679 Munich, Germany

Telephone +49 (o)89 2180-2740, Telefax +49 (o)89 2180-17845, email office@cesifo.de

Editors: Clemens Fuest, Oliver Falck, Jasmin Gröschl

www.cesifo-group.org/wp

An electronic version of the paper may be downloaded

- from the SSRN website: $\quad$ www.SSRN.com

- from the RePEc website: $\quad$ www.RePEc.org

- from the CESifo website: www.CESifo-group.org/wp 


\title{
The Brexit as a Forerunner: Monetary Policy, Economic Order and Divergence Forces in the European Union
}

\begin{abstract}
We analyze the effects of the increasingly expansionary monetary policies on the economic order and on the European integration process. We argue that the market orders shaped in postwar Germany and in Margret Thatcher's United Kingdom have long served as cornerstones for growth, prosperity and social cohesion in Europe. It is shown that the monetary policies of the European Central Bank and the Bank of England have undermined these orders, thereby eroding productivity gains and growth. Combined with negative distribution effects, ultra-loose monetary policies constitute the breeding ground for divergence forces in the European Union as heralded by the Brexit.
\end{abstract}

JEL-codes: B250, E580, E650.

Keywords: European integration, economic order, Walter Eucken, Friedrich August von Hayek, Margret Thatcher, inequality, monetary policy, political polarization, divergence, Brexit.

\author{
Sebastian Müller \\ Leipzig University \\ Institute for Economic Policy \\ Grimmaische Straße 12 \\ Germany-04109Leipzig \\ sebastian.mueller@uni-leipzig.de
}

\author{
Gunther Schnabl \\ Leipzig University \\ Institute for Economic Policy \\ Grimmaische Straße 12 \\ Germany - 04109 Leipzig \\ schnabl@wifa.uni-leipzig.de
}




\section{Introduction}

A decade after the outbreak, the European financial and debt crisis remains unsolved. Although growth rates have recovered, unemployment is declining and the German real estate market is becoming overheated (Bundesbank 2018), the European Central Bank continues to buy large amounts of government bonds. In the United Kingdom growth has recovered, but productivity growth is low and the Brexit is causing increasing uncertainty. The tightening of monetary policy keeps being delayed.

The debate about the future of the European Union is controversial. The European Commission (2017) proposes a further deepening through the completion of the banking union, the enlargement of the European Monetary Union and the creation of a common European ministry of finance. This institutional integration approach is in the French tradition of aiming to create a centrally-directed and central bank-financed Europe with harmonized living standards as an economic and political counterweight to the USA (Trichet 2011).

In contrast, the functional European integration approach ${ }^{1}$ was based on the German ordoliberal thinking of free markets combined with price stability (Eucken 1952). It was joined by the United Kingdom's reforms under Margret Thatcher. ${ }^{2}$ Since then, Germany and the United Kingdom - together with some smaller northern European countries such as the Netherlands - sought to strengthen market principles within the European Union.

While the institutional and functional integration have long been balanced in the European integration process, Sinn (2016) argues that the Brexit has changed the majorities in the EU in favor of the institutional integration. Given a majority of southern European countries in the board of the European Central Bank, also the likelihood of a central bank-financed common European budget has increased. As will be shown, the very fact that growing government expenditure in Europe - both at national and supra-national level - is increasingly financed via central banks, strengthens the divergence forces in the European Union, as heralded by the Brexit.

1 The distinction between functional and institutional integration goes back to Balassa (1961). A distinctive feature is the varying degree of willingness of the participating countries to renounce the economic sovereignty. Both areas of integration are interconnected because market integration requires common institutions that regulate the integration process.

2 Both the order by Eucken (1952) and the Thatcher reforms were based on Hayek (1944, 1945, 1968). 


\section{Economic Order and Growth in Europe from a Historical Perspective}

The economic order of a country is rooted in its institutional and cultural traditions. As Europe has been traditionally politically fragmented and exposed to competition among institutions, it experienced an outstanding economic development. After World War II, different growth models prevailed in Europe, with the gradual opening of markets in some parts of Europe enhancing growth and prosperity throughout Europe.

\subsection{Institutional Competition in Europe from a Historical Perspective}

Historically, Europe has been politically fragmented, especially compared to large states in Asia such as China and India. ${ }^{3}$ Tocqueville (1835, 166-168) saw many middle-sized nations in Europe as the cradle of political freedom, because a small population limits the power of the sovereigns. Institutional competition leads to a decentral distribution of resources, which are therefore not available to an individual ruler in their entity. ${ }^{4}$ Hence, resources cannot be wasted by powerful sovereigns, but are employed to benefit citizens. ${ }^{5}$ According to (Hayek 1944) large states are incapable to conform with different preferences of various regions and customs. As he regarded uniform rules as inefficient, he recommended to strictly limit the leeway for supranational institutions that create common rules for a group of states. ${ }^{6}$

Hume (1742) emphasized the importance of competition between political entities for learning processes if countries are linked by trade and migration. He referred to ancient Greece, where competition among independent city-states had created a fertile climate for

3 See Montesquieu (1748, 283-284): "In Asia one has always seen great empires; in Europe they were never able to continue to exist. This is because the Asia we know has broader plains ... and its smaller rivers form slighter barriers. ... Therefore, power should always be despotic in Asia." In Europe, the natural divisions form many medium-sized states in which the government of laws is not incompatible with the maintenance of the state; on the other hand, they are so favourable to this that without laws this state falls into decadence and becomes inferior to all the others."

4 "The temptations that the government offers to ambition are too weak and the resources of private individuals are too slender for the sovereign power easily to fall into the grasp of a single man." (Tocqueville 1835, 166).

5 "The efforts and resources of the citizens are turned to the internal well-being of the community and not ... likely to be wasted upon an empty pursuit of glory." (Tocqueville 1835, S. 165).

6 "There must be a power which can restrain the different nations from action harmful to their neighbours, a set of rules what a state may do, and an authority capable of enforcing these rules. The powers which such an authority would need are mainly of a negative kind, it must above all, be able to say 'No' to all sorts of restrictive measures... But this does not mean that a new super-state must be given powers which we have not learned to use intelligently even on a national scale, that an international authority ought to be given power to direct individual nations how to use their resources." (Hayek 1944, p. 231). See also Vaubel (2008). 
arts and sciences resulting in a flowering of culture. ${ }^{7}$ Weede (2008) deduces the emergence of property rights from institutional competition in Europe, because the existence of different governments enabled comparison, which lead to competition for a preferable institutional design of the state. Salmon (1987) sees "Yardstick Competition" to create positive incentives. If people - who disagree with the economic and political design - are able to leave, ${ }^{8}$ the incentive for decision-makers to grant private property rights increases.

\section{Figure 1: Per Capita Income in Different World Regions from Historical Perspective}

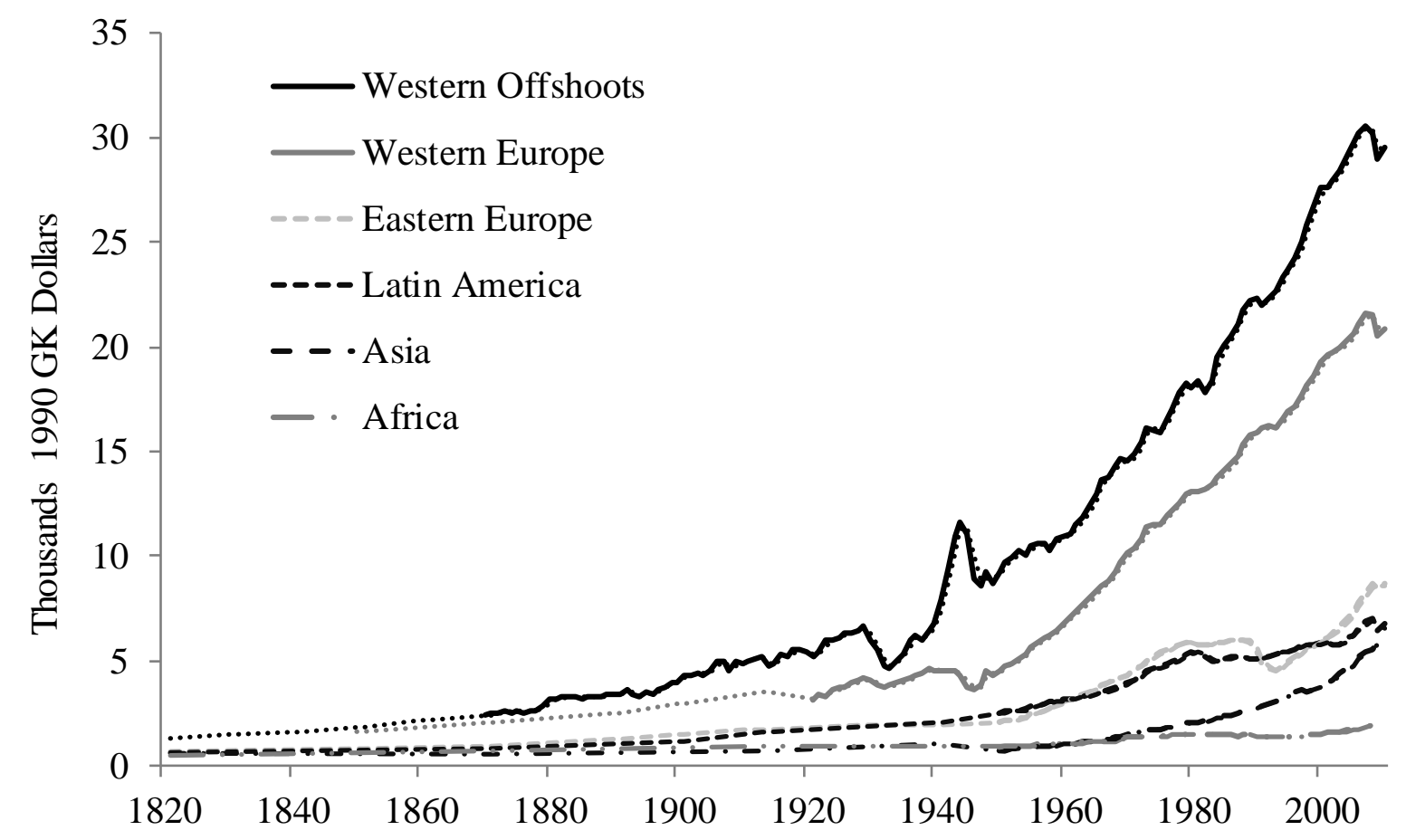

Source: Maddison Project.

Property rights favor technical progress through competition as a discovery procedure (Hayek 1968). The prospect of retaining profits increases the incentive for innovation. The existing knowledge is used efficiently and new knowledge is generated. Given competition among firms, innovations are tested on the market and imitated if successful. The resulting productivity and wealth gains are particularly clear for Europe in a historical global comparison: Since the $18^{\text {th }}$ century, per capita incomes in Europe and European influenced offshoots have risen much faster than in the rest of the world (Figure 1).

7 "There concurred a happy climate, a soil not unfertile and a most harmonious and comprehensive language so that every circumstance among that people seemed to favour the rise of the arts and sciences. Each city produced its several artists and philosophers who refused to yield the preference to those of the neighbouring republics." Hume (1742, p. 121).

8 On 'Exit und Voice' see Hirschmann (1970). 
World War I constituted a caesura for institutional competition in Europe, as the war favored inward-focused economic development tilted towards the production of war-related goods and food, with the economies becoming directed by state-led cartels (Röpke 1950). Gerwarth (2016) argues that after World War I the dissolution or large multinational entities such as the Austrian-Hungarian empire, imperial Russia and the Osman empire destroyed open borders within and beyond these multinational states. This reduced competition, with the new national states becoming greenhouses for cartels (Röpke 1950). The resulting weakening of economic activity favored further trade disintegration leading to low growth, with the resulting slow-down of growth culminating in World War II.

\subsection{Different Post-war Growth Models and European Integration}

After World War II, two different growth and central bank models prevailed in Europe (De Grauwe 2012, 151-152). In the Anglo-French model, central banks pursued several objectives, in particular the stabilization of the business cycle and high employment. Price stability was only one of several objectives and the central banks' decisions were subject to government's (i.e. the ministries of finance's) approval. Central bank-financed government expenditure was seen as a tool to stimulate growth. Therefore, since the $1970 \mathrm{~s}^{9}$, high inflation rates in southern and western Europe resulted in devaluations of currencies against the German mark (Gros and Thygesen 1998).

In contrast, in Germany, the central bank was independent, following the objective of price stability as a primary target. Low inflation encouraged high savings rates, which ensured low risk premiums on interest rates, thereby favoring investment. The independence of the Deutsche Bundesbank required that government expenditures had to be mainly financed by taxes and therefore had to be kept tight. Some smaller neighboring countries, which were economically strongly intertwined with Germany such as the Netherlands and Austria closely followed the German growth model via tight exchange rate pegs to the German mark.

The depreciation of currencies transfers foreign growth to the domestic economy, because the resulting changes in relative prices reduce imports and increase exports (beggar-thy-neighbor, Smith 1827). From the point of view of a Prisoner's Dilemma, trading partners tend to retaliate by depreciating their currencies to counteract the negative growth effects on their economies. The consequence were competitive depreciations, which had destabilized the world economy

9 Until then, the common membership of all Western European countries in the Bretton Woods system had kept the exchange rates of Western European currencies to each other largely stable. Adjustments of parities against the dollar (for example, the appreciation of the Deutsche Mark in 1961) were rare. 
economically and politically during the 1930s. Such competitive depreciations did not set in in Europe, because Germany remained committed to a stable currency. This allowed parts of German growth to be shifted to the southern and western European neighboring countries.

Germany did not depreciate her currency, because the ongoing European integration process opened via the removal of barriers to trade and other factor flows larger markets for German enterprises. This enabled German enterprises to realize substantial economies of scale in industrial production. From this point of view, the different growth models in Europe can be seen as complementary. The productivity gains, which were generated in Germany and some smaller neighboring countries thanks to a stable monetary regime and the opening of the European markets, were partially distributed via the depreciations of the southern and western European currencies across whole Europe. With the common agricultural policy and European regional policy, additional redistribution channels were put in place.

\section{Figure 2: Per Capita GDP Income in EU Core Countries}

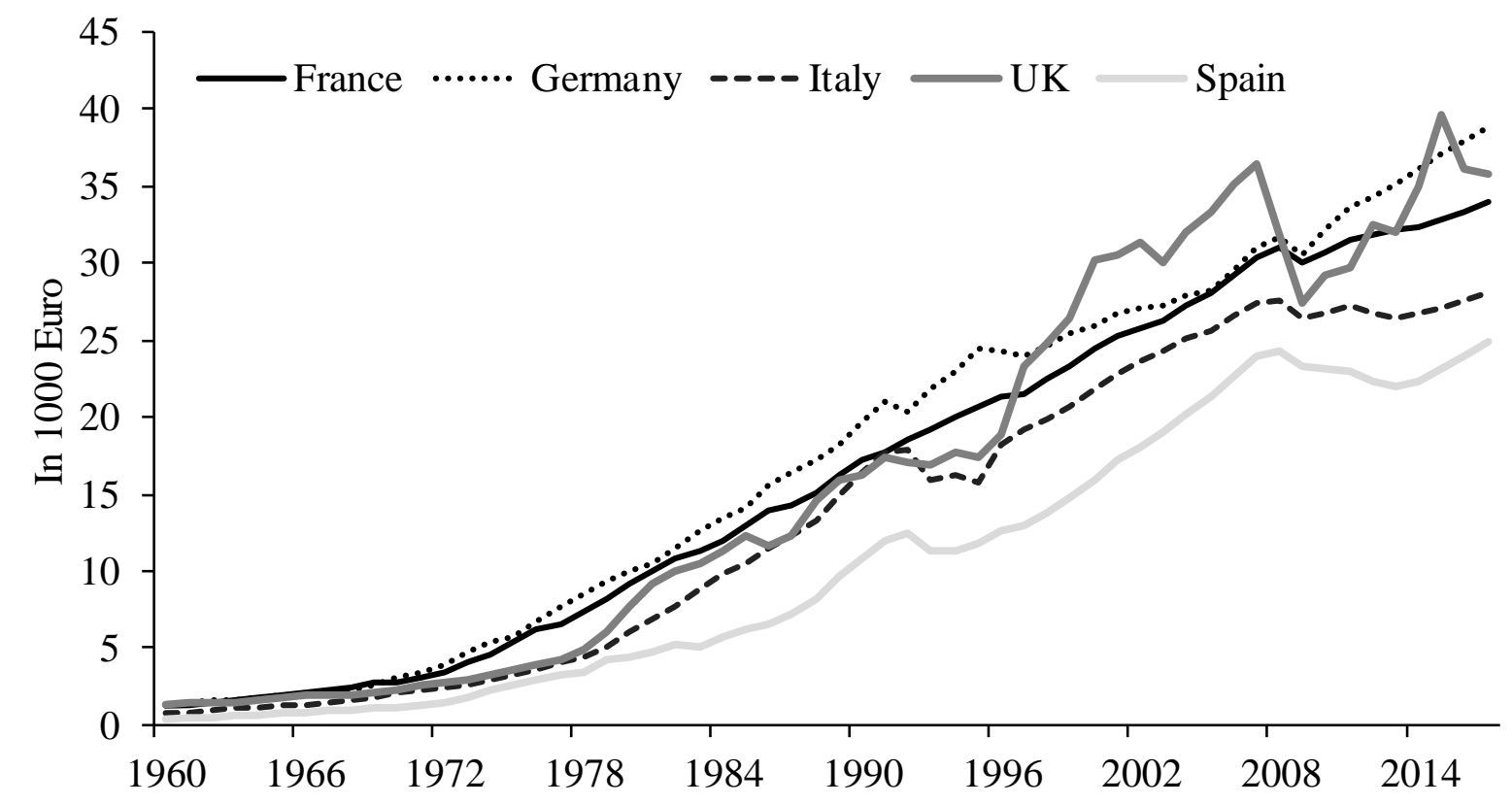

Source: Thomson Reuters Datastream.

The upshot is that the growth rates of per capita incomes in Western Europe remained strongly intertwined despite different growth models (Figure 2). The mutual interest in European integration was reflected in the continuing deepening of the EU, which entailed both institutional and functional integration elements. The Single European Act (1986), which perfected the four freedoms - free movements of goods, services, labor and capital - can be seen as the accomplishment of the functional integration. The resulting growth of income levels 
favored the steady expansion of European institutions, which came along with the gradual transfer of competences to the supranational level. One peak of the institutional integration process was the creation of the European Central Bank (ECB) in 1999.

\subsection{German Ordolibe ralis $m$ and Thaterism as Pillars of European Cohesion}

Since Germany has been the largest European economy, the German economic order has been central for the European integration process. ${ }^{10}$ German ordoliberalism (Eucken 1952, Miksch 1937, Böhm 1950 and Erhard 1957) defined eight free market-oriented constitutive principles as framework for the private economic action, which should also shield off the government from the influence of interest groups. ${ }^{11}$

The main principle of the economic order designed by Eucken (1952) was decentralized decisions in free markets with free prices. Companies had to compete with each other in order not to be able to shape prices politically (constitutive principle 1). A stable money (constitutive principle 2) should ensure that high inflation does not distort price signals to prevent false signals for investment. Markets should be open (constitutive principle 3) to enhance competition between the largest possible number of (small) companies. This should ensure that prices were low and production was geared toward consumers' preferences.

Private property (constitutive principle 4) should create incentives to strive for profits, innovations and efficiency to benefit the whole society in form of rising real wages and growing tax revenues. Building on private property, all actors in economic affairs should within legally prescribed limits ${ }^{12}$ - be able to freely design contracts (constitutive principle 5). The privatization of profits implied conversely that losses are to be borne by entrepreneurs. This liability principle (constitutive principle 6) made the responsibility for one's own actions compelling to ensure efficiency-oriented decision making by enterprises. This should prevent economic agents from taking excessive risks, with losses being not transferred to the public.

Economic policy should be constant and forward-looking (constitutive principle 7) to make intended and unintended consequences of economic policy interventions be better

10 The post-war German economic system was rooted in the experiences of the monopolization and cartelization of the late Weimar Republic. The failure of the first German democracy was closely linked to the seizure of control of the great monopolies by the undemocratic forces. This resulted in a command economy, which became transformed into the war economy.

11 The constitutive principles of Eucken (1952) were not implemented in their pure form in Germany either. For example, from the outset large companies have been involved in Germany's economic policy decisions, e.g. in exchange rate policy in the wake of the breakdown of the Bretton Woods system.

12 In particular, no cartels should be allowed. 
understood. Given constant economic policy, investments can be better planed, which favors growth. According to Eucken (1952), in complex systems such as market economies, many factors are closely intertwined. The constitutive framework was therefore regarded to only work if all the principles were fulfilled at the same time ${ }^{13}$ (constitutive principle 8).

The success of the German economic order was reflected in high economic growth (the socalled Wirtschaftswunder), which resulted in buoyant imports from other European countries. Income levels in whole Europe increased (Figure 2). Considerable productivity gains allowed not only for a significant increase in wage levels in western Europe, but also the steady expansion of the welfare states. The growing scale of redistribution was already rooted in the German economic order with the four regulative principles of Eucken (1952). ${ }^{14}$ These encompassed redistribution and environmental protection should ensure that the principle of individual responsibility was consistent with the idea of social equality (see Müller-Armack 1950/1982 and Erhard 1957).

The European integration process reflected both the constitutive and the regulative principles. The liberalization of factor markets (functional integration) transmitted the principles of competition, free prices and liability to European goods, services, capital and labor markets. The idea of social equality, as enshrined in the regulatory principles, became anchored via the creation of common European institutions in supranational policies such as European agricultural and regional policy. The European Constitution adopted in 1993, which marks a milestone of the institutional integration, established the convergence of living conditions in Articles 174-178 of the European Treaty.

The market-oriented reforms under Prime Minister Margret Thatcher (1979-1990) constituted a fundamental shift of the British economic policy from government-led, central bank-financed demand management towards the rule of market forces (Card and Freeman 2004). The Thatcher reforms correspond to the constitutive principles of German ordoliberalism. ${ }^{15}$

13 Contractual freedom in the case of monopolies for instance leads to monopolists overstating prices. Competition without liability can lead to speculation at the expense of the public.

14 The first regulative principle called for a cartel authority to control the market behavior of large companies and to prevent or dissolve monopolies. High inequality, which could possibly result from free market processes, should be corrected by state intervention (regulative principle two). This was achieved via a progressive tax system. The third regulative principle provided for the correction of negative externalities, such as environmental pollution. The state should also intervene in the event of abnormal developments in the labor market, such as long working hours or child labor (regulative principle four).

15 "She reversed what her mentor, Keith Joseph, liked to call "the ratchet effect", whereby the state was rewarded for its failures with yet more power." https://www.economist.com/blogs/blighty/2013/04/margaret-thatcher. 
Government expenditure was curtailed by transferring the competence for monetary policy decision from the Treasury to an independent monetary policy committee (Card and Freemann 2004, 11). This shifted the focus of macroeconomic policy from the pursuit of full employment towards the control of inflation. Industrial policy was abandoned, public enterprises were privatized and subsidies were cut. The inflation rate fell from $27 \%$ in 1975 to $2.4 \%$ in 1986 .

The balance in industrial relations was changed in favor of employers, with laws enacted to weaken trade unions. ${ }^{16}$ To encourage private initiative and entrepreneurship the top tax rate was cut from $60 \%$ to $40 \%$. To enhance competition and efficiency large behemoths such as British Telecom, British Airways, British Steel, British Gas and the British Airports Authority were privatized and restructured. The public was encouraged to buy shares to broaden private participation in capitalism. Council tenants were encouraged to buy the homes they lived in to make them operate outside the welfare state.

While, in 1973, Thatcher had supported the accession of the United Kingdom to the European Union, ${ }^{17}$ she continued stressing that Europe was an entity going far beyond the European Union (Troitino 2009, 132-133). Europe should be a union of European states, without concentration of power in the supranational institutions. Therefore, Margret Thatcher limited the centralization process by restricting successfully payments to the European Community (No, no, no! / I want my money back!). ${ }^{18}$ In 1990 she rejected propositions to extend the powers of the European Parliament and the European Commission (Thatcher 1990).

Living conditions in Europe should be improved by using the European integration process as a tool to promote individual initiative and entrepreneurship, with the state remaining limited to a supervisor in the system (Thatcher 1995). To achieve this target Thatcher promoted the Single European Act (1986), which became the first wide-ranging constitutional reform of the European Union (Troitino 2009, 131). Realized by 1992, the common market led to the free movements of goods, services, capital and labor among all

16 For instance, the employment Acts of 1980, 1982, 1989 and 1990, the Trade Union Act 1984 and the Public Order Act 1986. The number of working days lost as a result of strikes fell from 29 million in 1979 to 2 million in 1986.

${ }^{17}$ Until then, the accession of the United Kingdom to the European Community was supported by German y, but prevented by France.

18 In her 1988 Bruges speech Thatcher declared: "We have not successfully rolled back the frontiers of the state in Britain, only to see them re-imposed at a European level, with a European super-state exercising a new dominance from Brussels." 
EU member states. ${ }^{19}$ The free market approach had from 1990 onwards a strong influence on the market-oriented reforms of the central and eastern European countries, which from 2004 joined the European Union.

The 'Big Bang' in October 1986 started a decisive deregulation of financial markets following the principles of free market competition and meritocracy. The reforms were based on technical innovation (from open-outcry to electronical trading), open access to trading (in particular for professional US agents) and the freeing of negotiations of commissions. As a result, international capital was attracted to the city of London, which constituted the basis for the rise of British income levels even beyond Germany and France (Figure 2).

Whereas Germany and the United Kingdom became in many cases aligned concerning their defense of market forces in Europe, their economic strengths were complementary. Germany relied on industrial production and the United Kingdom on financial market services. $^{20}$ Industrial-based growth in Germany provided an incentive to irrevocably stabilize intra-European exchanges rate by joining the monetary union. The strength of the financial sector generated high growth the United Kingdom also without outright exchange rate stabilization. This facilitated the opt out from the European Monetary Union.

\title{
3. Monetary Policy and the Gradual Erosion of Market Principles
}

\begin{abstract}
“(...) though I strongly sympathise with the desire to complete the economic unification of Westem Europe by completely freeing the flow of money between them, I have grave doubts about doing so by creating a new European currency managed by any sort of supra-national authority. Quite apart from the extreme unlikelihood that the member countries would agree on the policy to be pursued in practice by a common monetary authority (and the practical inevitability of some countries getting a worse currency than they have now), it seems highly unlikely that it would be better administered than the present national currencies." (Hayek 1990, 24)
\end{abstract}

The climax of the institutional European Integration so far can be seen in the introduction

19 Nevertheless, the Single European Act came also along with growing power for the common European institutions such as the European Parliament. The cooperation in economic policy making and monetary integration was strengthened as well as the pursuit of social cohesion via regional funds and common agricultural policy.

${ }^{20}$ Germany has a large surplus in goods trade, the United Kingdom a large surplus in service trade. 
of a common currency. ${ }^{21}$ Hayek (1990) foresaw two major deficiencies of the European Monetary Union. First, the common monetary policy was unable to cope with heterogeneous economic developments. Second, the European Central Bank gradually moved away from a stability-oriented German central bank model, as it was designed in European treaties, acting increasingly like former southern European central banks prior to the European Monetary Union (Schnabl 2017). By opting out from membership in the European Monetary Union the United Kingdom maintained its ability to respond to asymmetric shocks, but the Bank of England's monetary policy became similarly expansionary by responding to financial market crisis with monetary expansion.

\subsection{The Failure of the Common Monetary Policy in a Heterogeneous Currency Area}

The business cycles of member states have to be synchronized to ensure the effectiveness of a monetary union (Mundell 1961). A high probability of so-called asymmetric shocks - as it has been the case between south and north of the currency union (Blanchard and Quah 1989) require a high degree of wage flexibility and/or labor mobility. ${ }^{22}$ As labor market regulations in most European countries have been traditionally limiting wage flexibility, fiscal policy has been central for the effectiveness of the common monetary policy from the outset.

A centralized fiscal policy (combined with a common social security system) can absorb asymmetric shocks. Tax revenues are declining in countries in recession, while they increase in booming countries. During an economic upswing, social security spending shrinks, while it increases during downswings. With tax collection and social security being centralized at the supranational level, idiosyncratic business cycles can theoretically be smoothed, because growing and falling tax revenues and social security payments cancel out against each other. The centralization of fiscal policies was, however, opposed both by the United Kingdom and Germany due to concerns that this would be the pre-step for growing central bank-financed redistribution within Europe (Starbatty 1997). Instead the subsidiarity principle and the need

\footnotetext{
21 A first initiative of a European economic and monetary union was raised by the European Commission in 1969 (Werner Plan). Although the plan was never realized, the initiative was re-launched in June 1988 and implemented in three consecutive stages based on the Delors Report. Despite the widespread believe in the benefits of a monetary union, many economists rejected a single currency (see Giers ch 1975, von Weizsäcker, 1971, Basevi, Fratianni, Giersch, Korte-weg, O’Mahoney, Parkin, Peeters, Salin und Thygesen 1975, Hayek 1976, Hayek 1990, Vaubel. 1974, Vaubel, 1978a, Vaubel 1990 and LeighPemberton 1990).

${ }^{22}$ In 1992, this was demonstrated by the crisis of the European Monetary System. The German unification had caused a boom in Germany and recessions in the neighboring countries, implying appreciation pressure on the German mark and depreciation pressure on the currencies of the neighboring countries. Speculative attacks on the British pound caused a deep recession in the United Kingdom, which was taken as an argument not to further participate in the European monetary integration process.
} 
for institutional competition were stressed.

If fiscal policies are not centralized - as it was the case for the European Monetary Union idiosyncratic business cycles have to be counterbalanced with discretionary fiscal policy decisions at the national level to ensure the effectiveness of monetary policy. Countries in recession have to raise public expenditure, whereas countries in boom have to cut spending. Otherwise, the common interest rate is too high for countries in recession (with unemployment rising) and too low for booming countries (driving up inflation). The Maastricht fiscal criteria were attempting to limit indebtedness to contain moral hazard in government spending, ${ }^{23}$ but were not designed to balance asymmetric shocks. Instead, from the start of the European Monetary Union national fiscal policies have been amplifying business cycles, causing a severe crisis.

Figure 3: Spending Paths in Europe since Euro Introduction

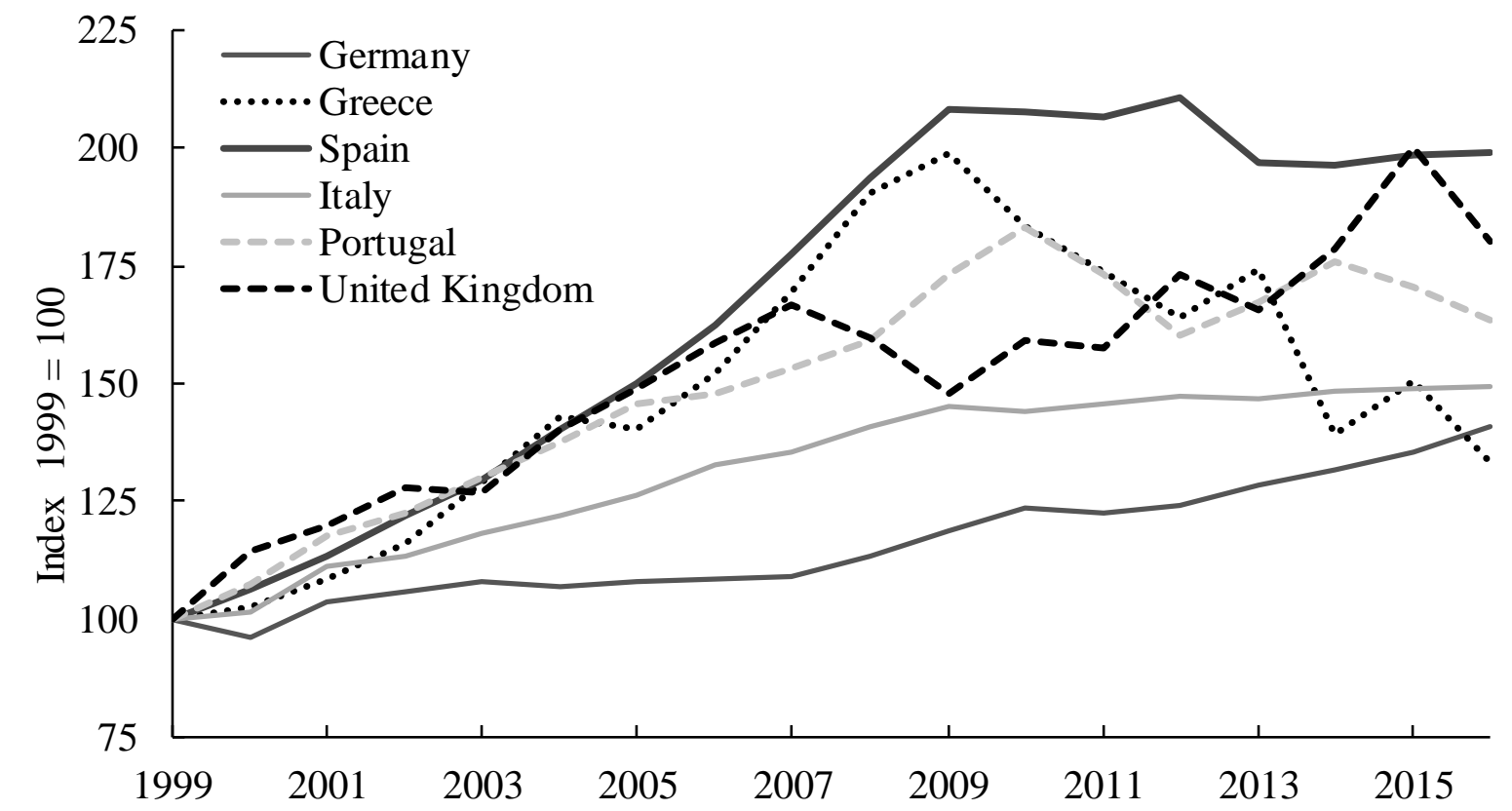

Source: IWF, World Economic Outlook. Public sector expenditure in euros.

Shortly after the introduction of the euro, the European Central Bank cut the main refinancing rate in response to the bursting of the dotcom bubble from 3.75\% in May 2001 to $1 \%$ in June

23 According to Ar. 126 of TFEU “(2) Member States shall avoid excessive government deficits. (2) The Commission shall monitor the development of the budgetary situation and of the stock of government debt in the Member States with a view to identifying gross errors. In particular, it shall examine compliance with budgetary discipline on the basis of the following two criteria: (a) whether the ratio of the planned or actual government deficit to gross domestic product exceeds a reference value, unless: ... (b) whether the ratio of government debt to gross domestic product exceeds a reference value, unless the ratio is sufficiently diminishing and approaching the reference value at a satisfactory pace." 
2003. The historically low level of interest rates increased the likelihood of financial market exuberance $^{24}$, while various members of the monetary union pursued different fiscal policy stances. $^{25}$ Germany pursued a restrictive fiscal policy stance, as - particularly because of the costly reunification - unemployment had risen sharply and public debt-to-GDP had reached the Maastricht limit of $60 \%$ in $1999 .{ }^{26}$ The government curtailed public spending and deregulated labor markets. The wage restraint in the public sector was transmitted to the private sector, which significantly reduced unit labor costs. The reform policies strengthened market forces and the competitiveness of the German economy (Burda and Seele 2016).

\section{Figure 4: Intra-European Current Account Imbalances}

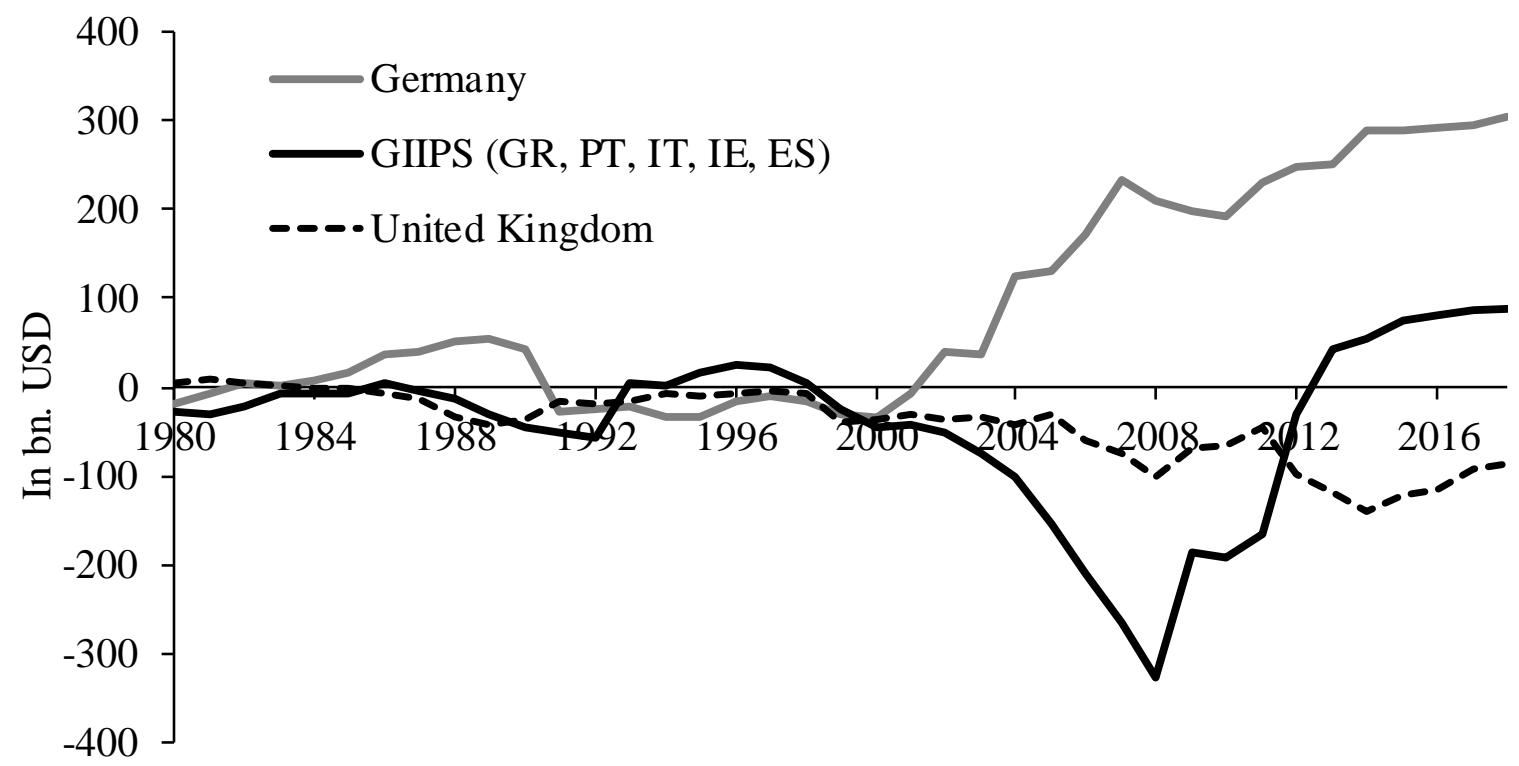

Source: IWF: World Economic Outlook. GIIPS = Greece, Ireland, Italy, Portugal and Spain.

The austerity in the public and private sector beclouded the business climate in Germany, causing investment and growth to decline after the turn of the millennium. Household savings

24 Based on the monetary overinvestment theory of Mises (1912) and Hayek (1931), Schnabl (2017) argues that too low interest rates lead to unsustainable investment booms and speculation in financial markets, therefore constituting the pre-step for crisis.

25 The different economic cycles within the European Monetary Union since the turn of the millennium are usually attributed to the interest rate convergence process in southern Europe (see Sinn and Wollmershäuser 2012). With the entry into the European Monetary Union, interest rate levels in the southern European countries converged to the low level of Germany. This encouraged growth and exuberance in southern Europe. The convergence hypothesis neglects, however, that similar credit-driven boom phases occurred outside the European Monetary Union (e.g. Iceland, many central and eastern European countries, the UK and the USA) at the same time. Also in the United Kingdom, the capital inflows from Germany boosted growth, employment and wages.

26 In the course of the German reunification, the western German wage level and welfare system had been transferred to the eastern part, although eastern German enterprises had a considerable lower productivity. 
increased as the government reduced pension entitlements and set incentives for private pension provision. Enterprise savings rose as unit labor costs fell and exports flourished. Tight fiscal policy together with wage austerity kept inflation low so that - given a common interest rate real interest rates were comparatively high. This had a negative effect on investment.

With growing savings being not absorbed by investments and government expenditure ${ }^{27}$ the fast-rising German savings surplus was exported via bank-lending to countries inside and outside the European Monetary Union (including the United Kingdom). The resulting capital inflows fueled boom phases in the recipient countries which translated into wages hikes, increasing consumption and increasing prices. Falling real interest rates encouraged investment as well as speculation in real estate and equity markets. The financial markets in London boomed. The resulting increase in tax revenues seduced to dramatic increases in government spending (Figure 3), which further reinforced the boom. The growing current account imbalances (Figure 4) symbolize the real divergence in the common currency area (and beyond). ${ }^{28}$ When capital flows reversed in 2007, the growing external debt positions of Ireland and the southern European countries led into an inevitable debt crisis. ${ }^{29}$

\subsection{Monetary Expansion and the Erosion of Market Forces}

While the southern and western periphery of the euro area slipped into crisis due to high external debt, German, British other northern European banks, which had provided credit during the boom, were threatened by defaults. The European Central Bank and the Bank of England reacted - similarly to the US Federal Reserve in the wake of the US subprime crisis - with an unprecedented monetary expansion (Figure 5). Key interest rates were cut (close) to zero. The balance sheets were strongly expanded by purchases of (predominantly) government bonds. The ultra-low monetary policies of the European Central Bank and the Bank of England prevented the collapse of financial institutions and governments. Growth, hesitantly, recovered. The downside is that the constitutive principles of the market-oriented order have become undermined (see Freytag and Schnabl 2017). First, the free-market interest rate mechanism has become disrupted. With interest rates being pushed towards zero both at the short (via

27 Net capital exports of a country are equal to the gap between saving and investment and therefore net capital exports (imports) and the current account balance. As a result, both net capital exports and current account balances of Germany increased strongly.

28 Since wages and prices in the periphery of the currency union rose faster than in Germany, the euro appreciated in those countries in real terms, whereas the German euro depreciated.

29 The outbreak of the US subprime market crisis in 2007 triggered a global reassessment of credit risk. As many German banks made losses in the US mortgage market, they were forced to reduce their foreign exposure. 
conventional monetary policy) and the long end of the yield curve (via unconventional monetary policy), the signaling function of interest rates is suspended. The low interest rates encourage high levels of indebtedness and distort default risks of banks, companies and governments. Likewise, rising equity and real estate prices do no longer reflect increasing efficiency but benign liquidity conditions. ${ }^{30}$

Figure 5: Money Market Interest Rates and Size of Balance Sheet

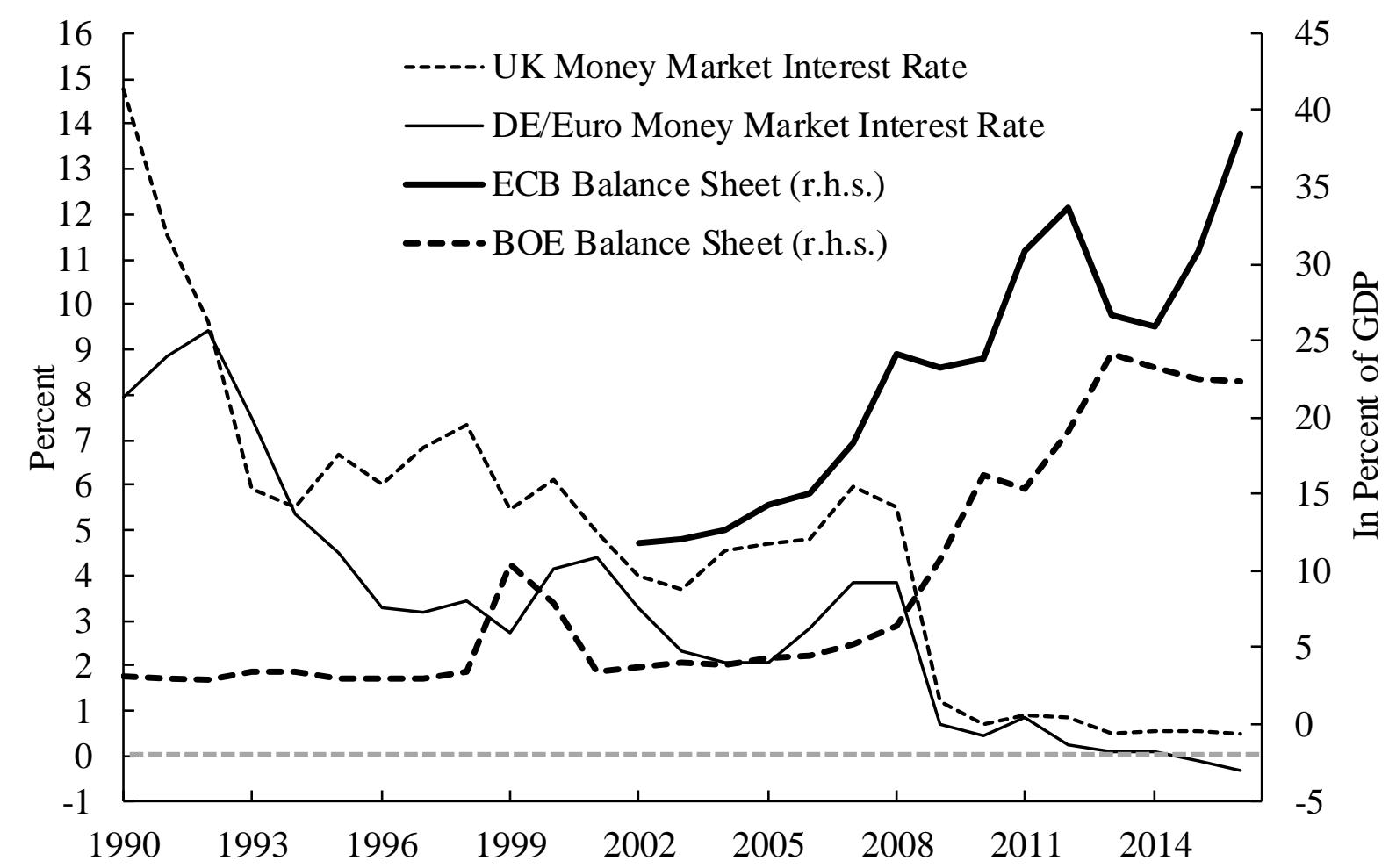

Source: IMF, World Economic Outlook, ECB, Eurostat. The German money market rate represents the euro area until 1998.

Second, monetary stability as a prerequisite for an efficient allocation of resources is undermined. Although prices of goods and services remain stable, the expansionary monetary policy has driven up prices in financial and real estate markets in erratic cycles. ${ }^{31}$ Artificially inflated asset prices distort investment decisions. Financial market speculation is encouraged at the cost of real investment. The boom and bust cycles in financial markets are linked to growing economic instability, which further discourages fixed capital

30 In addition, the unintended side effects of excessive monetary expansion in the form of rising rents and low wages have created incentives for price controls in real estate and labor markets if form of rental price brakes and minimum wages.

31 Pre-cris is, stock and real estate prices exploded in southern Europe, Ireland and other European countries. Now, the exuberance has shifted to Germany (see Schnabl 2017). 
investment.

Third, the bailout of financial institutions distorts competition. In crisis, large financial institutions are likely to be rescued through recapitalizations because they are considered to be too big to fail. If monetary expansion persists (as since 2008), the margins between credit and deposit interest rates are squeezed (Gerstenberger and Schnabl 2017). Large financial institutions can better compensate for the loss of this traditional source of revenue by investment banking, where economies of scale matter. In contrast, small and medium financial institutions are forced to merge or are taken over by larger competitors.

Fourth, private ownership in financial markets is restricted, if in crises collapsing financial institutions are nationalized (for example Commerzbank in Germany, Northern Rock in the United Kingdom). Ultra-loose monetary policy is equivalent to hidden nationalization, if interest rates are persistently held low to prevent instability of the financial sector. Caballero, Hoshi and Kashyab (2008) have created the notion of zombie banks, which keep non-profitable enterprises alive to prevent bad loans from becoming visible in their balance sheets.

Fifth, freedom of contract in financial markets is undermined, because financial exuberance is followed by growing regulation (macroprudential measures) to prevent new crises in the future. Since the onset of the European debt crisis, both at the national and European level, extensive documentation requirements and higher equity provisions are restraining the business activity of banks. As large banks have more resources at hand to cope with the incurred costs, regulation distorts competition at the benefit of large entities.

Sixth, the liability principle is undermined. In the low-interest driven boom phases, profits from excessive credit growth and speculation in financial markets are privatized. When during crisis fragile financial institutions are recapitalized or stabilized by monetary expansion, the potential losses are shifted to the public. The anticipation of monetary rescue operations increasingly undermines the liability principle through moral hazard.

Seventh, as the growing monetary expansions has inflated financial markets, the likelihood and size of crises has increased, necessitating a growing scale of rescue measures. The unintended side effects of large policy interventions (Hoffmann and Schnabl 2016) entail new economic policy interventions (intervention spirals, Mises (1949, 712-729), with the principle of constant economic policy making being undermined.

Thus, from a financial market perspective none of Eucken's (1952) constitutive principles is fully fulfilled any more, neither in the euro area and nor in the United Kingdom, nor in 
the rest of the EU.

\section{Growth and Distribution Effects as Catalysts for Political Divergence}

As the very loose monetary policies slow down growth and lead to negative distributional effects, they form the breeding ground for political polarization that jeopardizers - as in the case of the Brexit - the achievements of the European integration process.

\subsection{Negative Growth Effects of Monetary Policy Rescue Operations ${ }^{32}$}

In the neoclassical theory, growth arises through the accumulation of capital until the economy converges to a long-run equilibrium of gross investment and depreciation (Solow (1956). This equilibrium (steady state) is based on the assumption that the marginal efficiency of investment diminishes with the size of the capital stock. Growth beyond this point is only possible if there is innovation (technological progress) (Solow 1957).

With the erosion of market principles in Europe, incentives for innovation and for increasing efficiency of the production processes have become gradually eroded. During boom phases, low or falling interest rates have triggered investment projects with low marginal efficiency because of relaxed financing constraints. During crisis, sharp interest rate cuts have kept investment projects with lower marginal efficiency alive. Persistently low interest rates are tying factors of production in projects with a low marginal efficiency. The average marginal efficiency of investment remains low. ${ }^{33}$

Leibenstein (1966) sees motivation and incentives as important determinants of a dynamic efficiency concept that goes beyond static allocation efficiency. Companies do not realize all potential efficiency gains when competition is limited. If ultra-loose monetary polic ies disturb competition, for instance by creating speculative profit opportunities through decreasing financing costs and by making bail outs predictable, innovations and the

32 The proponents of the "secular stagnation" thesis assume that decreasing investment and low growth are predetermined. A flood of savings resulting from the aging of societies meets falling investment, which leads to falling real interest rates (see Summers 2014). Monetary policy simply adjusts to this process. The explanation provided in this paper for declining interest rates and low growth is in clear contrast to the secular stagnation hypothesis, as the low growth environment is attributed to policy failure.

33 This is in line with Mises's (1949) and Hayek's (1945) view, that undue monetary expansion disturbs an efficient allocation of resources. If prices signals (e.g. interest rates) are distorted, unproductive investment decisions are made (Hayek 1945). 
associated efficiency gains shrink, with competition as a discovery procedure (Hayek 1968) being disturbed.

The empirical literature, which associates low interest rates and declining productivity gains, is growing. Borio et al. (2016) show that during credit-driven booms, labor is shifted to low-productivity investment projects, resulting in a lower average productivity. ${ }^{34}$ Peek and Rosengren (2005) see a misallocation of capital across the credit sector in Japan, which keeps companies with poor earnings prospects alive ("ever-greening").Gerstenberger (2017) shows for Germany that the improved financing conditions since 2008 have been accompanied by falling productivity gains for small and medium enterprises. Gopinath et al. (2015) argue, that the significant decline in productivity gains in southern Europe since the crisis has been linked to the misallocation of capital. Barnett et al. (2012) show for the United Kingdom that productivity gains have fallen sharply since 2007.35

Kornai (1986) coined the concept of soft budget constraints for the socialist planning economies. As the central governments feared unemployment, state-controlled banks provided cheap credits to unproductive firms. The losses of the banks were covered by the central banks via the printing press. The result was inefficient capital stock, weak innovation activity as well as low - or even negative - growth. Discontent in the population grew because consumer goods were scarce and of poor quality.

Figure 6 shows investment as percent of GDP, productivity growth and real growth in Germany and the United Kingdom since 1990. In Germany, which has been the growth engine of Europe up to the present, investment as a percent of GDP has gradually declined accompanied by shrinking productivity gains and real growth. In the United Kingdom productivity growth has also declined towards zero. While growth in the United Kingdom has recently recovered due to the depreciation of the pound against the euro, investment as percent of GDP and productivity gains remain sluggish.

34 In the subsequent crisis, this process is not completely reversed.

35 Note that pre-crisis productivity gains in the United Kingdom have been mainly driven by increasing turnover in the financial sector, which is constraint since then. 
Figure 6: Investment, Productivity Growth and Growth in Germany and UK

\section{Germany}

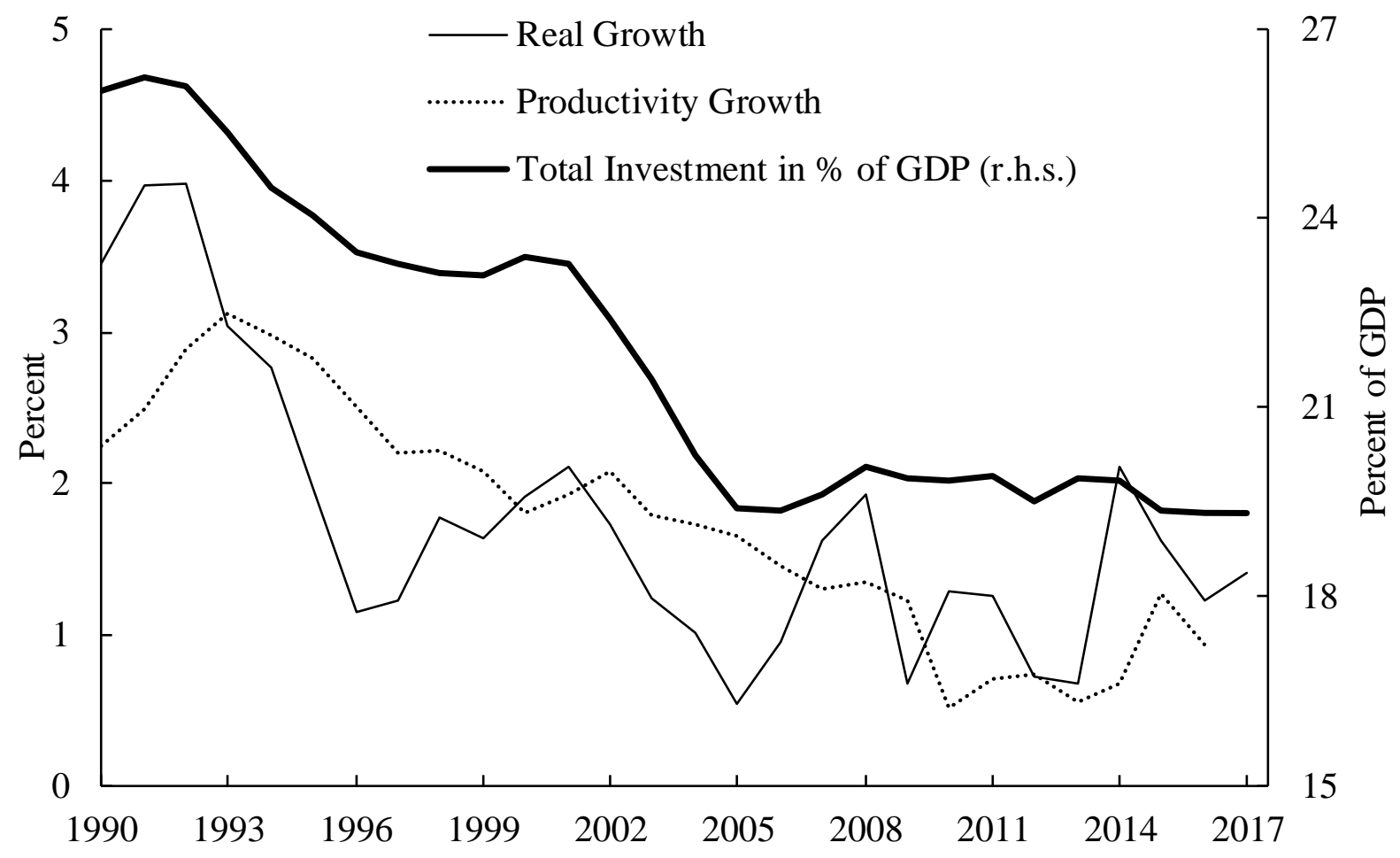

\section{United Kingdom}

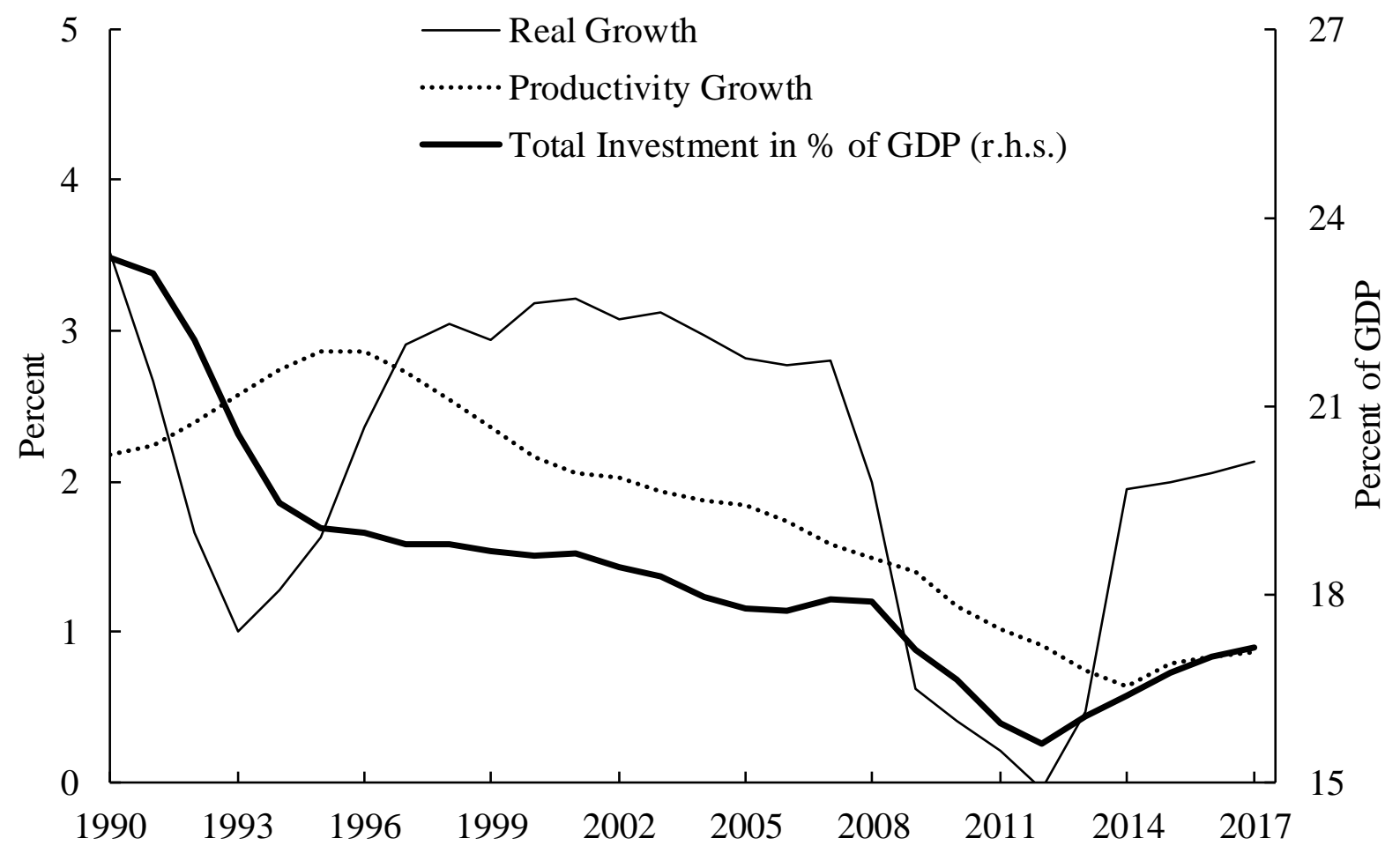

Source: OECD: Economic Outlook. Smoothed based on 5-year averages. 


\subsection{Distributional Effects}

The ultra-expansionary monetary policies of the European Central Bank and the Bank of England have distributional effects at the national levels (Hoffmann and Schnabl 2016). ${ }^{36}$ They work via the impact of ultra-expansionary monetary policies on productivity increases (see 4.1.) which restrict the scope for real (and nominal) wage increases. The impact of the benign liquidity conditions on asset prices and the economic structure has redistribution effects, which are partially counteracted via redistribution on a national and supranational level.

First, with interest rates being cut towards zero and large amounts of government bonds being purchased by central banks, the public sector benefits at the expense of the private sector. The hard budget constraint on public expenditure is eased with high debt levels becoming sustainable due to low interest rates. The burden is shifted to the private sector via lower interest rate payments on the outstanding government bonds and on private bank deposits.

Second, expansionary monetary policies favor the financial sector as the newly created money of central banks arrives there first (Cantillon 1931). Banks can extend their credit volume. Furthermore, banks can buy shares, real estate and securities at prevailing market prices. Once the newly created money trickles through the economy, asset prices are rising, thereby inflating the value of financial institutions' assets. If asset market bubbles burst, central banks contain losses of financial institutions with further monetary expansion. ${ }^{37}$

This results in a redistribution in favor of the first mover (financial sector) at the costs for those who are further away from central bank liquidity, i.e. households and enterprises (Cantillon effect). As persistently low interest rates paralyze growth and foster wage stagnation, the enterprises in real sector of the economy suffer from deteriorated sales perspectives. This effect gets smaller, when the traditional banking sector becomes regulated after the bursting of credit or asset prices bubbles.

Third, with asset prices being driven upwards, ultra-loose monetary policies make the wealthy people richer, because equity and real estate is primarily concentrated in higher-income classes. By contrast, interest rates on bank deposits, which makes up a large proportion of middle and

\footnotetext{
36 Non-EMU countries such as Switzerland import the monetary policy stance of the ECB via more or less tight exchange rate pegs.

37 Therefore, salaries in the financial sector, particularly in investment banking and asset management, have risen significantly faster than in the industrial sector during the last decades.
} 
low income groups' savings, have been pushed to zero.

Forth, there are distributional effects between young and old, as pressure on wages (originating in depressed productivity gains) does not affect all age cohorts equally. For the elderly, wage levels tend to remain high and jobs tend to remain secure during the creeping crisis. In contrast, for new entrants in the labor market, wages and pension entitlements are reduced compared to previous generations. The share of employment forms with part-time and temporary contracts is rising. ${ }^{38}$ If young people want to acquire assets, in particular real estate, the price in terms of yearly incomes has dramatically increased. A home has become increasingly difficult to afford. If both partners work, family planning is postponed and the number of children declines. ${ }^{39}$

Figure 7: Nominal Wage Development in EU Core Countries

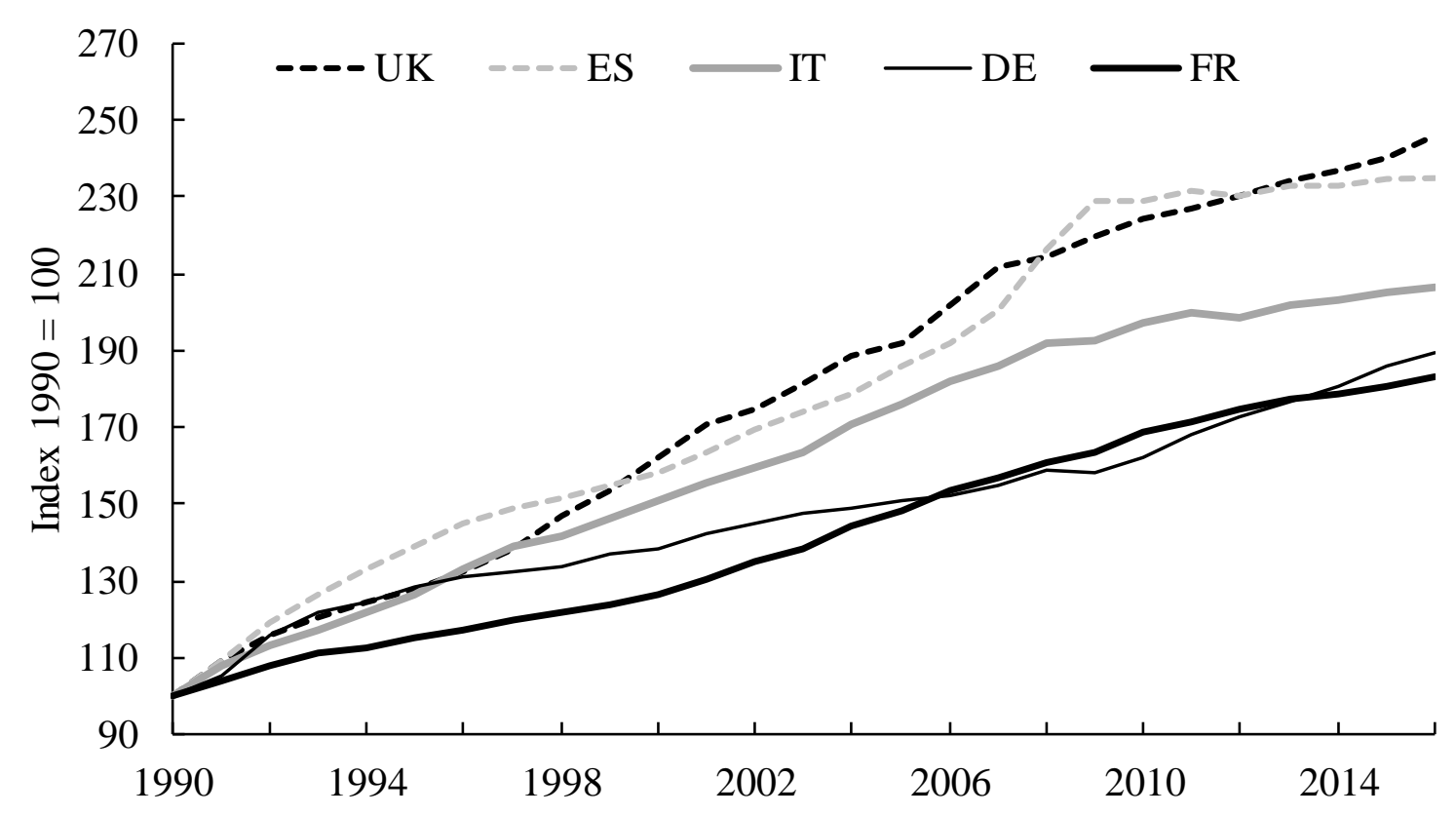

Source: OECD.

The restraint in wages has hit different European countries at different points of time. In Germany, nominal wages have tended to stagnate already from the mid 1990s (Figure 7) due to negative growth effects of the reforms. The resulting productivity gains were mainly exported via capital outflows (and current account surpluses) to other European countries (instead of being used for real wage increases), in particular the southern, eastern and western European

38 In southern Europe, the low interest rate in response to the bursting of the dot-com bubble has favored financial exuberance from 2003 to 2007. Since the bursting of the bubble, very low interest rates prevent a sustainable economic recovery, so as young people face difficulties finding jobs.

39 Low birth rates and a progressive aging of societies are putting pension and health insurance systems into distress. As governments are trying to maintain social security systems with high subsidies, the pressure of additional purchases of government bonds by central banks increases. 
ones (Figure 7). In the capital inflow recipient countries, real wages could grow beyond productivity gains.

Since the crisis, wage levels in the crisis countries are under downward pressure, as private capital inflows have dried out. In Germany, nominal and real wages are slightly increasing since then, as a bubble in the real estate market and the export sector has substantially reduced the supply in labor markets. The United Kingdom profited from buoyant capital inflows into the financial sector since the mid 1990s, which allowed substantial nominal (and real) wage increases up to outbreak of global financial crisis in 2008. Since then, less net capital inflows, growing financial regulation and uncertainty linked to the Brexit put a restraint on wage increases (Figure 7).

Fifth, large economic entities benefit at the cost of small entities. Because unconventional monetary policies depress the margin between lending and deposit rates, they erode the main source of income of the traditional banking business (i.e. credit provision). In contrast, the benign liquidity conditions inflate asset market transactions (including mergers and acquisitions), making in particular investment banking profitable. As in asset markets economies of scale matter, large (investment) banks benefit at the cost of small and medium (lending-oriented) banks. ${ }^{40}$ Therefore, gradual interest rate cuts toward zero have for long promoted the development of London's financial markets, where investment banking is clustered.

Sixth, large enterprises benefit relative to small enterprises because they have access to lowinterest rate capital market financing. In the course of unconventional monetary policies, the European Central Bank and the Bank of England have bought even bonds of large enterprises. Both factors have driven up prices of stock-listed enterprises. Small and medium-sized enterprises, by contrast, remain dependent on bank loans. As monetary policy puts small and medium sized banks in a precarious position, credit provision to small and medium enterprises is constraint. With the help of cheap financing conditions, large enterprises can take over smaller competitors. With the increasing concentration in the corporate and financial sectors, salaries of top managers are rising.

Seventh, if large financial institutions and companies and their suppliers are concentrated in certain regions, the regional economic structure changes. The economic centers, where large companies are clustered, are growing. The regions, where only small and medium enterprises

40 See Gerstenberger and Schnabl (2017) on the resulting concentration process in the Japanese banking sector. 
are located, are shrinking. In the search for jobs, young people have to move from the periphery to the economic centers. Within Europe, London has profited from Margret Thatcher's Big Bang, with London not only reaping the benefits from financial liberalization. The city has also benefitted like Luxemburg or Switzerland from the redistribution effect of the increasingly loose monetary policies in favor of the financial sector and in for of rich people. In Germany regions have gained, where large enterprises and their subcontractors are located (for instance Bavaria and Baden-Württemberg). As the ultra-low monetary policies have also favored government expenditure and regulation, centers of public administration such as Brussels, Paris, Rom, and Berlin have gained.

Eighth, there has been redistribution across borders within the European Union via three channels. First, the institutionalized redistribution channels are the common agricultural policy (CAP) and the regional funds. Here, the southern European countries and particularly France can be regarded as the main beneficiaries, with the United Kingdom, Netherlands and Germany being the largest net payers. Second, from the turn of the millennium net capital outflows, which have been mainly driven by benign liquidity conditions combined with uncoordinated fiscal policy stances, constituted an important channel of redistribution within Europe. Up to the year 2008, the southern and eastern European countries as well as the United Kingdom can be seen as the main beneficiaries of buoyant capital inflows, with Germany being at providing side. ${ }^{41}$

Ninth, since the outbreak of the crisis, the TARGET2 balances within European System of Central Banks have served as an important channel of redistribution (Sinn and Wollmershäuser 2012). Germany, Luxemburg, Netherlands and Finland are redistributing wealth to other member states of the European Monetary Union. Since 2007, the TARGET2 claims of Deutsche Bundesbank have grown from zero to over 900 billion euros, corresponding to a nonrepayable, unlimited, non-interest-bearing credit (Sinn 2016). Other redistribution channels with similar effects are the European Stability Mechanism (ESM) and other rescue facilities. The United Kingdom does not have to contribute to the TARGET2 stabilization measures, because of having opted out from the European Monetary Union.

\subsection{Shrinking Approval Rates and Political Polarization}

According to Rawls (1972), an order is considered to be just if all people have equal freedoms and opportunities, and social and economic inequalities bring the greatest benefit

41 As the net capital exports are reflected in growing German current account surpluses, it can be assumed that the German export enterprises benefit at the cost of the German savers (whose savings are devalued in the course of financial crisis). 
to the least favored. ${ }^{42}$ The German economic order aimed to ensure equal freedoms and opportunities. As economic freedom delivered high productivity gains, real wages increased for all parts of the population, including the least favored. The social security system could be expanded continuously, ensuring the acceptance of the economic order and the support for the major ruling parties.

The German economic order was crucial for the European integration process, because it favored high growth in Europe. This ensured the political acceptance of the expansion of the four freedoms, as the liberalization of European markets was associated with prosperity gains. The completion of the common market was supported by the market-oriented reforms in the United Kingdom. Germany and the United Kingdom became as the largest net payers the economic pillars of the further proceeding institutional integration in the European Union.

This redistribution was accepted in the United Kingdom as long as the development in the financial sector ensured substantial wage increases for most parts of the population (Figure 7). In Germany, the political elites accept the redistribution in favor of other European countries because the large export-oriented industrial sector continues to gain via large current account surpluses. Furthermore, the ruling parties seem to remain committed to the European idea, which they associate with the necessity to provide more financing to the European Union.

The redistribution between the member states of the European Union remained limited as long as it was carried over national budgets and required the consent of each individual country in the European Council. ${ }^{43}$ This has changed, however, with the common monetary policy. Pre-crisis, comparatively low interest rates combined with fiscal austerity in Germany triggering high German net capital exports to its neighboring countries (which are very unlikely to be repaid). Since the outbreak of the crisis, zero interest rates and large government bond purchases of the ECB constitute a redistribution channel, which is out of parliamentary control.

The changes in the TARGET2 balances - which come along with the extensive government bonds purchases of the ECB - have relaxed the budget constraint for southern crisis countries

42 The so-called differential principle states: "that the social and economic inequalities attached to offices and positions are to be adjusted so that, whatever the level of those inequalities, whether great or small, they are to the greatest benefit of the least advantaged members of society." (Rawls 1993, S. 6-7).

43 Germany's net payments to the European Commission in 2016 amounted to around 14 billion euros, the UKs net payment to 8.6 billion euros. 
at the expense of Germany and some smaller neighboring countries. The resulting loss of welfare for Germany is currently hidden by the build-up of a real estate and export bubble ${ }^{44}$, which is inflating - as in the southern European countries prior to the crisis - the tax revenues. Once, this bubble bursts, the TARGET2 balances and its implications for the real wage level are likely to gain more public attention.

The monetary policy rescue measures contribute to rising political polarization in Europe, because they undermine the economic orders in Germany and the United Kingdom, which have for long served as economic pillars for the institutional integration process. In Germany, incentives for enterprises to increase productivity have gradually vanished. In the United Kingdom, the global financial crisis and the resulting regulations have eroded the performance of the financial sector, with liquidity flows being redirected towards the enterprise sector.

As productivity gains converge to zero, the European integration process is increasingly becoming a zero-sum game. In contrast to the 1950s to 1990s, transfers in favor of the common institutions and of other European countries necessitate tax increases and/or wage austerity, which is changing the mood of major parts of the population. With wage levels for growing parts of the population declining or having reached low levels, immigration is increasingly understood as a threat. The free mobility of labor within the European Union is put into question (like in the United Kingdom) and refugees are causing unease (like in Germany).

The upshot is, that in parliamentary elections the votes for the traditional parties, which have been supporting the European integration process for decades, are fading. As shown in the left panel of the upper row of Figure 8 the shares of extreme left and right parties in parliamentary elections are growing as an arithmetic average of all EU28 countries. Whereas in the early 1990 s the share was $11 \%$, it has increased towards $24 \%$ by 2017 . As shown in the center and right panel of Figure 8, the polarization has on average taken place at the extreme right of the political spectrum. The character of political polarization is, however, dependent on the country group.

The lower row of Figure 8 shows that the political polarization process in the southern European countries has mainly gained momentum since the outbreak of the crisis and it

44 Real estate prices in economic centers shoot up, because interest rates are depressed and concerns about the loss of the value of the currency are growing. Exports are boosted, because the low interest rate combined with a still comparatively tight fiscal policy stance favor capital outflows. 
tilted towards the extreme left. (Before the crisis buoyant capital inflows allowed for real wage increases and growing government expenditure, causing satisfaction with the ruling parties.) This may reflect the believe that redistribution from the northern European countries will continue helping to solve the crisis. The government bond purchases of the European Central Bank are understood as an important move towards this direction. Indeed, since the 1970s, monetary expansion (at the national level) had boosted growth in this region via beggar-thy-neighbor policies. The strategy is expected to continue.

In contrast, the political polarization process in northern and eastern Europe is tilted towards the extreme right (second row of Figure 9). This may be due to the fact, that prior to 1990 soft budget constraints and monetary easing have been at the roots of economic decline and political repression. The citizens of the former planning economies seem not keen to return to such systems by voting for the extreme left. Because the central and eastern European countries have lost major shares of the population due to migration to the Western European countries (including the United Kingdom), they understand immigration of refugees as major threat to their cultural identity.

In the western and northern European countries including Germany the rise of rightwing populist parties reflects concerns of growing parts of the population about their personal material future and/or about the stability of the currency. As wage pressure is - in the public debate - often attributed to open markets and open borders (to deflect from policy failures), fears of free trade and the free movement of labor are fueled. ${ }^{45}$ Economic and political nationalism becomes a promising strategy to gain votes, as demonstrated by the Brexit, the slogan "France First" or the Italian Five Star Movement.

As shown in Figures 8 and 9 the political polarization dynamics in Europe, are intertwined with monetary policy. The graphs include an indicator for the monetary conditions in the European Monetary Union (which are similar in the United Kingdom), which shows the arithmetic mean of money market interest rates from 1990 to 2012. From 2013 onwards, the money market rates are substituted by a shadow interest rate proxy which converts the extensive bond purchases of the European Central Bank into interest rate cuts. This results in a negative shadow interest rate.

45 See for instance Rodrik (2017). This ignores that for decades globalization and European integration have been the basis for productivity gains and therefore rising wage levels for all parts of the population. 
Figure 8: Voting Shares of Extreme Left and Right Parties in Parliamentary Elections and Shadow Money Market Rate

EU28 (arithmetic average)

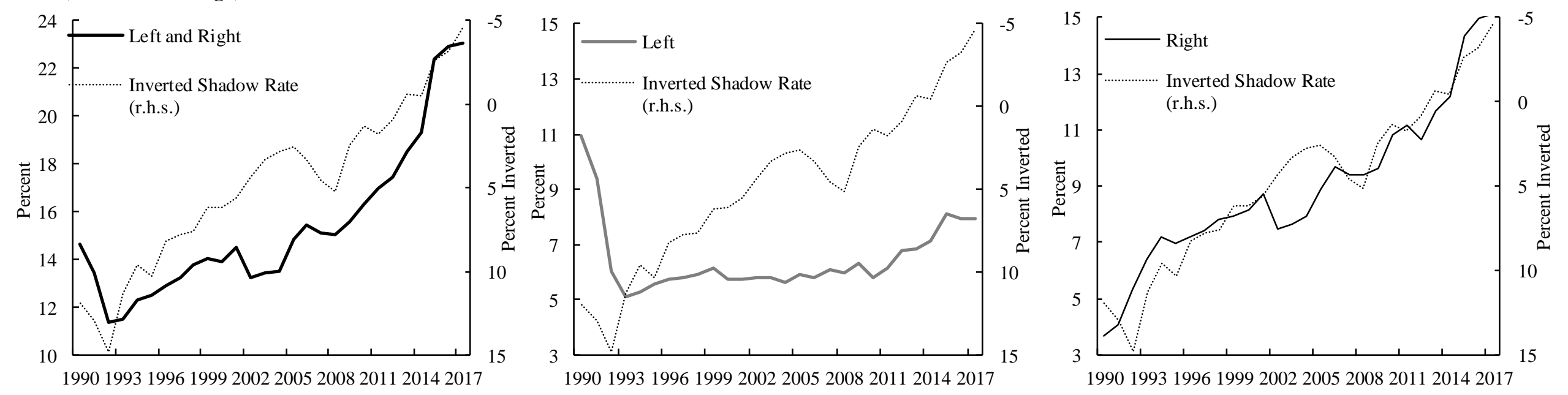

Southern European crisis countries (Greece, Italy, Portugal, Spain, Cyprus) (arithmetic average)
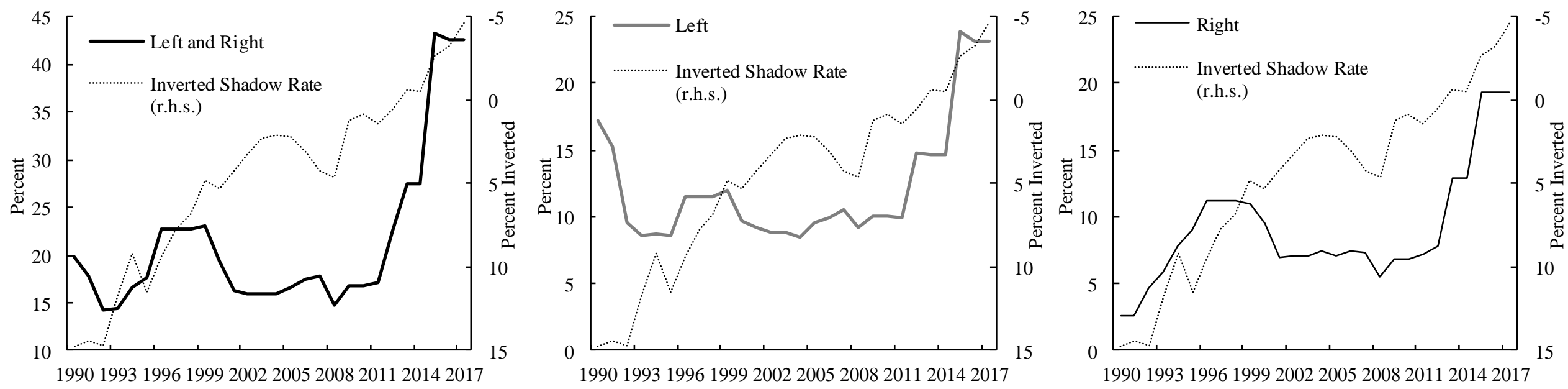

Source: OECD, Wu and Xia (2017). Calculations on voting shares based on data from Parties and Election in Europe. The categorization as extreme left and right follows Funke et al. (2015). Average European money market rate until 2013. Then approximated by Wu and Xia (2017). 
Figure 8: Voting Shares of Extreme Left and Right Parties in Parliamentary Elections and Shadow Money Market Rate

EU28 excluding southern European crisis countries (arithmetic average)

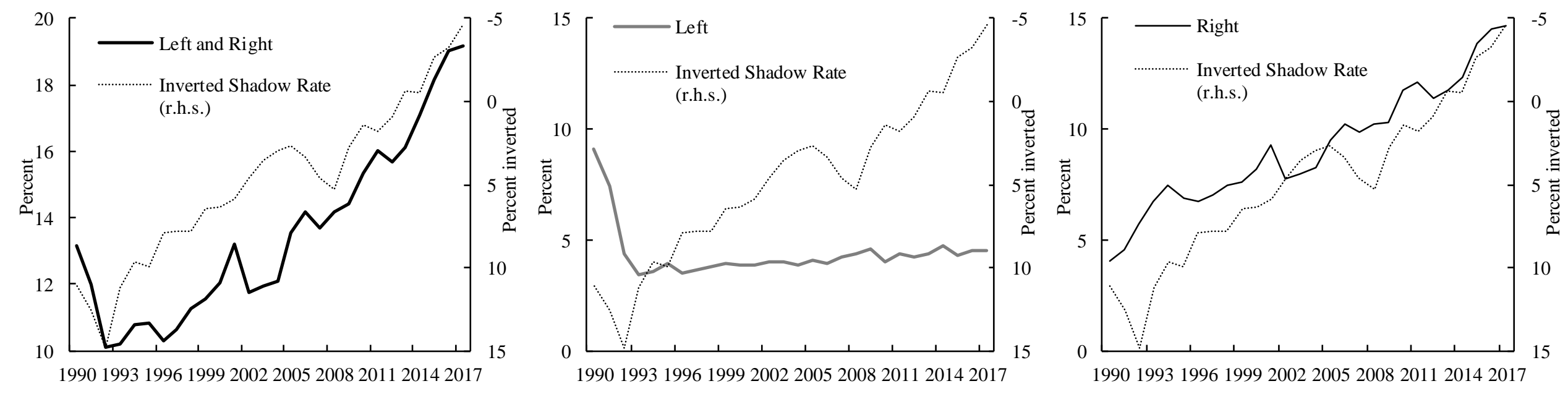

Central- und Eastern Europe (Bulgaria, Estonia, Croatia, Latvia, Lithuania, Poland, Romania, Slovenia, Slovakia, Czech Republic, Hungary) (arithmetic average)
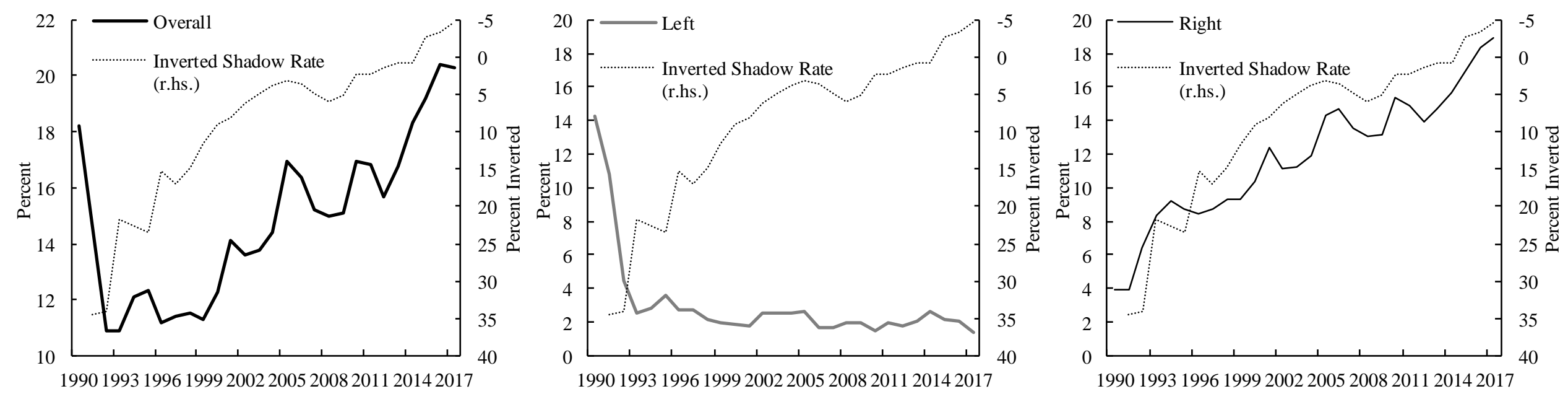

Source: OECD, Wu and Xia (2017). Calculations on voting shares based on data from Parties and Election in Europe. The categorization as extreme left and right follows Funke et al. (2015). Average European money market rate until 2013. Then approximated by Wu and Xia (2017). 
Causality in both directions is conceivable. On the one hand, increasingly loose monetary policies are leading to negative growth and distribution effects (see 4.1 and 4.2), so more discontent voters turn away from the established governing parties. Rising populism weakens the established parties on the national level and erodes the acceptance for the common European institutions. This tempts established parties and the common institutions to spend more to conciliate voters by showing to counteract growing inequality.

Because the necessary resources are not generated by growth anymore (with the economic order in Europe being heavily disturbed), the European Central Bank and the Bank of England have to purchase government bonds to keep government expenditure sustainable. As this further erodes the market order, a vicious circle of growing public expenditure, monetary expansion, slowing growth and political polarization is endangering the achievements of the European integration process. This is even more the case, because the rise of nationalistic movements favors the build-up of barriers to factors, which further erodes growth.

A divergence process is looming as heralded by the Brexit, the declared independence of Catalonia, the intended separation of Scotland or the northern league in Italy. A further deepening of the European Union cannot stop this process, as it needs financing by even more monetary expansion, which further erodes growth and increases inequality. Currently that process is still softened as the benign liquidity conditions provided by the ECB are boosting growth, being represented by vivid economic dynamics in Germany. However, as soon as this boom is over, the economic and political divergence process in Europe is likely to accelerate. The Brexit is the forerunner of this upcoming fragmentation process, possibly because the United Kingdom has a longer tradition of opposing centralization in the European Union (Young 1993).

\section{Outlook}

For a long time, Europe's prosperity was based on competition between institutions, which has generated high income and welfare levels. After World War II, the economic orders promoted by Ludwig Erhard and Margret Thatcher laid the foundations of the European integration process as they generated the economic basis for real wage increases, social justice and the common European institutions. As long as the financing of Europe's common institutions was based on decisions of the European Council, the extend of redistribution was limited by parliamentary control. As long as the German central bank was not included in the European System of Central Banks, the stable German mark built 
the backbone of high growth in Europe.

With the creation of the European Central Bank and the launch of financial market stabilization via monetary expansions, the economic fundament of the European integration process has been destroyed. The European Central Bank has shifted the political balance in favor of the institutional integration and growth models being-based on central bankfinanced government spending. This has eliminated the competition of orders in Europe, on which Europe's prosperity was based on. With German and British growth dynamics fading, a divergence process in Europe has set in, which is driven by stagnating wages levels for increasing parts of the population and socially undesired redistribution effects of monetary policy.

The call for solidarity in Europe is coming along with increasing financing needs for the common European institutions. As growth prospects and productivity gains are dim, those policies are likely to be financed by the ECB. With monetary expansion further paralyzing growth, social cohesion and redistribution in the European Union are increasingly a zerosum-game. This constitutes an incentive for northern, central and eastern European countries to leave the European Monetary Union and the European Union. Therefore, the Brexit is not a random policy mistake or a negative side effect of globalization. It is moreover the first milestone in a painful disintegration process Europe is heading for.

To save the European Union from major disruptions linked to such a disintegration process - as currently observed in the United Kingdom - a return to the institutional competition as stressed by Hume (1742), Tocqueville (1935) and Hayek (1944) is necessary. A Europe being based on free markets and subsidiarity would - given free factors flows in the common market - increase the welfare of the Europe people thereby strengthening the European Union. To achieve this goal the common European institutions have to accept that a stable euro is the very fundament of growth in Europe. 


\section{References}

Barnett, Alina / Chiu, Adrian / Franklin, Jeremy / Sebastiá-Barriel, Maria (2014): The Productivity Puzzle: a Firm-Level Investigation into Employment Behavior and Resource Allocation over the Crisis. Bank of England Working Paper 495.

Basevi, Giorgio / Fratianni, Michele / Giersch, Herbert / Korteweg, Peter, O’Mahoney, David /Peeters, Theo / Parkin, Michael / Salin, Pacal / Thygesen, Niels (1975). All Saints Day Manifesto for European Monetary Union: A Currency for Europe. The Economist, 1. Nov. 1975, 33-38.

Blanchard, Olivier / Quah, Danny (1989): The Dynamic Effects of Aggregate Demand and Supply Disturbances. American Economic Review 79, 4, 655-673.

Böhm, Franz (1950): Die Idee des ORDO im Denken Walter Euckens. Dem Freund und Mitheraus geber zum Gedächtnis. ORDO: Jahrbuch für die Ordnung von Wirtschaft und Gesellschaft 3, 15-64. Balassa, Bela (1961), The Theory of Economic Integration. Irwin, Homewood, Illinois.

Borio, Claudio / Kharroubi, Enisse / Upper, Christian / Zampolli, Fabrizio (2016): Labour Reallocation and Productivity Dynamics: Financial Causes, Real Consequences. BIS Working Papers 534.

Bundesbank (2018): Konjunktur in Deutschland. Monatsbericht Februar, 46-58.

Burda, Michael C./ Seele, Stefanie (2016). No role for the Hartz reforms? Demand and supply factors in the German labor market, 1993-2014. SFB 649 Discussion Paper, 2016-010.

Caballero, Ricardo / Hoshi, Takeo / Kashyap, Anil (2008): Zombie Lending and Depressed Restructuring in Japan, American Economic Review 98, 5, 1943-1977.

Cantillon, Richard (1931): Abhandlung über die Natur des Handels im allgemeinen, Jena.

Card, David / Freeman, Richard B. (2004): What have two decades of British economic reform delivered?. In: Seeking a Premier Economy: The Economic Effects of British Economic Reforms, 1980-2000, University of Chicago Press, 9-62.

De Grauwe, Paul (2012): The Economic of Monetary Union. Oxford: Oxford University Press.

Erhard, Ludwig (1957): Wohlstand für Alle. Düsseldorf: Econ-Verlag.

Eucken, Walter (1952): Grundsätze der Wirtschaftspolitik. Tübingen und Zürich: Mohr Siebeck und Polygraphischer Verlag.

Europäische Komission (2017): Reflection Paper on the Deepening of the Economic and Monetary Union. 31.05.2017. https//ec.europa.eu/commission/sites/betapolitical/files/reflection-paper-emu_en.pdf

Freytag, Andreas / Schnabl, Gunther (2017): Monetary Policy Crisis Management as a Threat to Economic Order. Credit and Capital Markets 50 2, 151-169. 
Funke, Manuel / Schularick, Moritz / Trebesch, Christoph (2015): Politics in the Slump: Polarization and Extremism after Financial Crises, 1870-2014. Unpublished, Free University of Berlin.

Gerstenberger, Juliane / Schnabl, Gunther (2017): The Impact of Japanese Monetary Policy Crisis Management on the Japanese Banking Sector. CESifo Working Paper 6440.

Gerwarth, Robert (2016): The Vanquished. Why the First World War Failed to End, 19171923, London: Farrar, Straus and Giroux.

Giersch, Herbert (1975): The Case for a European Parallel Currency. In: Marjolin, Robert, Report of the Study Group 'Economic and Monetary Union 1980' and Annex I (the Marjolin Report), 77-83. Link: https://www.cvce.eu/obj/the_marjolin_report_brussels_march_1975-en-93d25b61$\underline{6148-453 \mathrm{~d}-9 \mathrm{fa} 7-9 \mathrm{e} 220 \mathrm{e} 874 \mathrm{dc} 5 . \mathrm{html}}$

Gopinath, Gita / Şebnem Kalemli-Özcan / Loukas Karabarbounis / Carolina Villegas-Sanchez (2017): Capital Allocation and Productivity in South Europe. The Quarterly Journal of Economics forthcoming.

Gros, Daniel / Thygesen, Nils (1998): European Monetary Integration: from the EMS to EMU. Harlow, England, New York: Addison Wesley Longman.

Hayek, Friedrich A. von (1931): Prices and Production. New York: August M. Kelly Publishers.

Hayek, Friedrich A. von (1944): The Road to Serfdom. Chicago: University of Chicago Press.

Hayek, Friedrich A. von (1945): The Use of Knowledge in Society. American Economic Review, 35, 4, 519-530.

Hayek, Friedrich A. von (1968): Der Wettbewerb als Entdeckungsverfahren.In: Internationales Institut „Österreichische Schule der Nationalökonomie" (Hg.), Die Österreichische Schule der Nationalökonomie, Texte - Band II von Hayek bis White, Manz'sche Verlags- und Universitätsbuchhandlung, Wien, S. 119-137.

Hayek, Friedrich A. von (1990): Denationalisation of Money: The Argument Refined. Auburn (AL): Ludwig von Mises Institute.

Hirschmann, Albert (1970): Exit, Voice and Loyalty. Responses to Decline in Firms, Organizations and States. Cambridge (MA): Harvard University Press.

Hoffmann, Andreas / Gunther Schnabl (2016): The Adverse Effects of Ultra-Loose Monetary Policies on Investment, Growth and Income Distribution. Cato Journal 36, 3, 449484.

Hume, David (1742/1985): Of the Rise and Progress of the Arts and Sciences. In: Miller, Eugene (Hg.), David Hume: Essays, Moral, Political and Literary, Liberty Fund, Indianapolis.

Juncker, Claude (2017): President Jean-Claude Juncker's State of the Union Address 2017. European Commission Press Release Database. 13.09.2017, URL: http://europa.eu/rapid/press-release_SPEECH-17-3165_en.htm. 
Kornai, Janos (1986): The Soft Budget Constraint. Kyklos 39, 1, 3-30.

Leibenstein, Harvey (1966): Allocative Efficiency vs. X-Efficiency. American Economic Review 56, 3, 392-415.

Leigh-Pemberton, Robin (1990): The United Kingdom's Proposal for Economic and Monetary Union. Bank of England Quarterly Bulletin, 30, 3, 374-377.

Miksch, Leonhard (1937): Wettbewerb als Aufgabe: die Grundsätze einer Wettbewerbsordnung. Stuttgart: Kohlhammer.

Mises, Ludwig von (1912): Die Theorie des Geldes und der Umlaufmittel. Leipzig: Duncker und Humblot.

Mises, Ludwig von (1919): Human Action. Scholar's Edition. Auburn (AL): Ludwig von Mises Institute.

Montesquieu, Charles (1748/1989): Montesquieu: The Spirit of the Laws. Cambridge: Cambridge University Press.

Müller-Armack, Alfred (1950/1982): Social Irenics. In: Stützel. Wolfgang, Christian Watrin, Hans Willgerodt und Karl Hohmann (eds.): Standard Texts of the Social Market Economy, Gustav Fischer, Stuttgart and New York, 347-359.

Mundell, Robert (1961): Optimum Currency Areas. American Economic Review 51, 4, 717 724.

Peek, Joe / Eric Rosengren (2005): Unnatural Selection: Perverse Incentives and the Misallocation of Credit in Japan. American Economic Review 95, 4, 1144-1166.

Piketty, Thomas (2014): Capital in the Twenty-First Century. Cambridge (MA): The Belknap Press of Harvard University Press.

Rawls, John (1972/1999): A Theory of Justice. Cambridge (MA): Harvard University Press.

Rawls, John (1993): Political Liberalism. New York: Columbia University Press.

Rodrik, Danny (2017): Populism and the Economics of Globalization. HKS Working Paper No. RWP17-026.

Röpke, Wilhelm (1950): International economic disintegration. Auburn (AL), Ludwig von Mises Institute.

Salmon, Pierre (1987): Decentralisation as an Incentive Scheme. Oxford Review of Economic Policy 3, 2, 24-43.

Schnabl, Gunther (2017): The Failure of ECB Monetary Policy from a Mises-Hayek Perspective. CESifo Working Paper 6388.

Sinn, Hans-Werner und Timo Wollmershäuser (2012): Target Loans, Current Account Balances and Capital Flows: The ECB's Rescue Facility. International Tax and Public Finance 19, 4, 468-508.

Sinn, Hans-Werner (2016): Der Schwarze Juni. München: Verlag Herder. 
Smith, Adam (1827): An Inquiry into the Nature and Causes of the Wealth of Nations. Edinburgh: Nelson and Brown.

Solow, Robert (1956): A Contribution to the Theory of Economic Growth. Quarterly Journal of Economics 70, 1, 65-94.

Solow, Robert (1957): Technical Change and the Aggregate Production Function. Review of Economics and Statistics 39, 2, 312-320.

Starbatty, Joachim (1997): Die politische Dimension des EURO: Zehn Thesen. Tübinger Diskussionsbeiträge 92.

Summers, Larry (2014): U.S. Economic Prospects: Secular Stagnation, Hysteresis, and the Zero Lower Bound. Business Economics 49, 2, 65-73.

Thatcher, Margaret (1990): Speech in the House of Parliament ("No. No. No!"), 30 October 1990, Link: https://www.margaretthatcher.org/document/108234.

Tocqueville, Alexis de (1835/1945): Democracy in America. New York.

Trichet, Jean-Claude (2011): A Centralized Europe is a Globalized Europe. Reuters Macroscope, 27.12.2011.

Troitiño, David Ramiro (2009). Margaret Thatcher and the EU. In: European Union: Current Political and Economic Issues. Tallinn: Tallinn University of Technology.

Vaubel, Roland (1974): Plans for a European Parallel Currency and SDR Reform: The Choice of Value-Maintenance Provisions and "Gresham's Law". Weltwirtschaftliches Archiv, $110,194-228$.

Vaubel, Roland (1978a): Strategies for Currency Unification. The Economics of Currency Competition and the Case for a European Parallel Currency. Kieler Studien 156, J.C.B. Mohr (Paul Siebeck) Tübingen.

Vaubel, Roland (1990): Currency Competition and European Monetary Integration. The Economic Journal, 100, 402, 936-946.

Vaubel, Roland (2008): A history of thought on institutional competition. In: Bergh, Andreas und Rolf Höijer (Hg.), Institutional Competition, Cheltenham, Elgar, Cheltenham (UK) and Nothampton (MA, USA), 29-66.

von Weizsäcker, Christian (2014): Public Debt and Price Stability. German Economic Review $15,1,42-61$

Weede, Erich (2008): Asia's giants in the world economy: China and India. In: Bergh, Andreas und Rolf Höijer (Hg.), Institutional Competition, Cheltenham: Elgar, Cheltenham (UK) and Nothampton (MA, USA), 230-260.

Wu, Jing Cynthia / Fan Dora Xia (2017): Time Varying Lower Bound of Interest Rates in Europe. Chicago Booth Research Paper, 17-06.

Young, John W. (1993): Britain and European unity, 1945-1992. New York: St. Martin's Press. 


\section{Appendix}

\section{Categorization of Parties}

The categorization of extreme left and right parties follows Funke, Schularick and Trebesch (2015). The spectrum of right-wing extremist parties includes parties of the "old" and "new" right. This group includes far-right extremism, right-wing populism and eurosceptic parties that reject the current European economic order. The spectrum of left-wing extremist parties includes parties that have communist and/or Marxist-Leninist positions, as well as parties whose policies are based on an anti-capitalist ideology and who also reject the current economic order.

\section{Table 1: List of Extreme Left and right Parties Since 1990}

Austria, AT

Left:

Right:

Belgium, BE

Left:

Right:

Bulgaria, BG

Left:

Right:

Cyprus, CY

Left:

Right:
Kommunistische Partei Österreichs (KPÖ).

Freiheitliche Partei Österreichs (FPÖ), Bündnis Zukunft Österreich (BZÖ).

Parti du Travail de Belgique (PTB-PvdA), Kommunistische Partij van Belgie (KPB/PCB).

Vlaams Belang (VB), Parti Populaire (PP), Front National (FN).

Bâlgarska Komunisticheska Partiya (BKP).

Ataka, Natzionalen Front za Spasenie na Bulgaria (NFSB), Обединени Патриоти (engl. United Patriots), Bălgarska Bez Cenzura (BBC).

Anorthotiko Komma Ergazomenou Laou (AKEL).

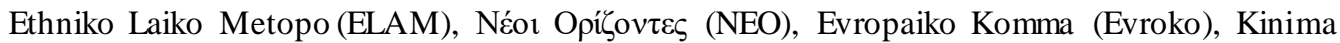
Allileggyi (KA).

Czech Republik, CZ

Left:

Komunistická Strana Čech a Moravy (KSČM), Komunistická strana Československa (KSČ).

Right:

Úsvit - Národní Koalice (ÚSVIT), Sdružení pro Republiku - Republikánská strana Československa (SPR-RSČ), Nezávislí demokraté (NEZDEM), Národní strana (NS), Dělnická strana sociální spravedlnosti (engl. Workers' Party).

Germany, DE Left:

Partei des Demokratischen Sozialismus (PDS) / die Linke, Marxistisch-Leninistische Partei Deutschlands (MLPD).

Right: $\quad$ Alternative für Deutschland (AFD), Nationaldemokratische Partei Deutschlands (NPD), Die Republikaner (REP), Bürgerbewegung pro Deutschland (PRO), Ab jetzt... Demokratie für Volksabstimmung (Volksabstimmung), Deutsche Volksunion (DVU), Pro Deutsche Mitte (pro $\mathrm{DM})$, Bund freier Bürger (BFB).

Denmark, DK

Left:

Enhedslisten - De Rød-Grønne (Enhl., Ø), Socialistisk Folkeparti (SF), Fælles

Kurs.

Right: Dansk Folkeparti (DF), Fremskridtspartiet. 
Left: $\quad$ Eestimaa Kommunistlik Partei (EKP), Eesti Vasakpartei (EVP), Eestimaa Ühendatud Vasakpartei (EÜVP).

Right: $\quad$ Eesti Iseseisvuspartei, (EIP), Eesti Konservatiivne Rahvaerakond (EKRE).

Spain, ES

Left:

Izquierda Unida (IU), La Izquierda Plural, Bloque Nacionalista Galego (BNG), Esquerra Republicana de Catalunya (ERC), Podemos, Unidad Popular, Unidos Podemos, Euskal Herria Bildu (EHB), Batasuna (HB) Euskadiko Ezkerra (EE).

Right:

France, FR*

Left:

Extrême gauche (EXG), La France Insoumise (FI), Front de gauche (FG), Parti communiste français (PCF), Revolutionary Communist League (LCR), Lutte Ouvrière (LO).

Right: Debout la France (DLF), Front National (FN), Divers extrême droite (EXD), Mouvement pour la France (MPF).

*Voting shares correspond tot he first ballot.

Finland, FN

Left:

Right:

Vasemmis toliitto (VAS), Suomen Kommunistinen Puolue (SKP).

Suomen maaseudun puolue (SMP), Perussuomalaiset (PS).

Greece, GR

Left:

Right:

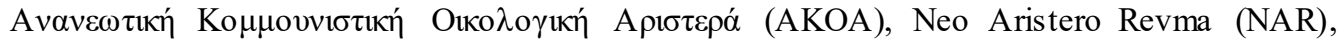

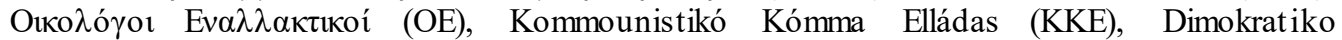
Koinoniko Kinima (DIMAR), Synaspismós Rizospastikís Aristerás (Syriza), Antikapitalistiki Aristeri Synergasia gia tin Anatropi (Ant.Ar.Sy.A), Laikí Enótita (LAE).

Chrysi Avyi (XA), Ethniki Politiki Enosis (EחEN/EPEN), Politiki Anixi (POLA), Laikós Orthódoxos Synagermós (LAOS).

Croatia, HR

Left:

Ljevica Hrvatske, Akcija Socijaldemokrata Hrvatske (ASH), Hrvatski Laburisti - Stranka Rada (HL-SR).

Right:

Hrvatski Demokratski Savez Slavonije i Baranje (HDSSB), Srpska Demokratska Stranka (SDS), Hrvatska stranka prava (HSP), Hrvatska kršćanska demokratska unija (HKDU), Hrvatska građanska stranka (HGS), Hrvatska stranka prava dr. Ante Starčević (HSP AS).

Hungary, HU

Left:

Right:

Magyar Munkáspárt, Hazafias Válas ztási Koalíció (HVK).

Jobbik Magyarországért Mozgalom (JOBBIK), Fidesz - Magyar Polgári Szövetség (Fidesz), Kereszténydemokrata Néppárt (KDNP), Független Kisgazda-, Földmunkás- és Polgári Párt (PkgP), Magyar Igazság és Élet Pártja (MIÉP).

Ireland, IR

Left:

Anti-Austerity Alliance-People Befoe Profit (AAA-PBP), Comhghuaillíocht an Phobail roimh Bhrabús (PBPA), Daonlathas Clé, Páirtí na nOibrithe (WP), Páirtí Sóisialach, Páirtí Sóisialach na nOibrithe (SWP), Sinn Féin (SF).

Right:

Italy, IT

Left:

Partito Comunista Italiano (PCI), Democrazia Proletaria (DP), Partito della Rifondazione Comunista (PRC), Partito dei Comunisti Italiani (PdCI), La Sinistra - L'Arcobaleno (SA), Partito Comunista dei Lavoratori (PCL), Sinistra Critica (SC), Sinistra Ecologia Libertà (SEL).

Right: Movimento 5 Stelle (M5S), Lega Nord (LN), Movimento Sociale Italiano - Destra Nazionale (MSI-DN), Alleanza Nazionale, AN (AN), Movimento Sociale - Fiamma Tricolore (MS-FT), Alternativa Sociale, Fratelli d'Italia (FdI).

Lithuania, LT

Left:

Lietuvos komunistų partija (LKP), Socialistinis liaudies frontas (SPF), Fronto partija (FRONTAS)

Right: Lietuvių tautininkų sajunga (LTS-NP), Partija „Jaunoji Lietuva“ (JL), Partija tvarka ir teisingumas (PTT)

Latvia, LV 
Left: $\quad$ Latvijas Komunistiskā partija (LKP), Latvijas Sociālistiskā partija (LSP).

Right: $\quad$ Nacionālā Apvienība (NA), ēvzemei un Brīvībai (TB/LNNK), Latvijas Nacionālās Neatkarỉbas Kustība (LNNK), Tēvzemei un Brīvỉbai/LNNK (TB/LNNK), Visu Latvijai! (VL), No sirds Latvijai (NSL).

Luxembourg, LU

Left:

Déi Lénk (LÉNK), Kommunistesch Partei Lëtzebuerg (KPL).

Right: $\quad$ National Bewegong (NB).

Malta, MT

Left:

Right:

Imperium Europa, Azzjoni Nazzjonali (AN), Alleanza Bidla (AB), Moviment Patrijotti Maltin (MPM).

Netherlands, NL

Left:

Socialistische Partij (SP).

Right:

Partij voor de Vrijheid (PVV), Staatkundig Gereformeerde Partij (SGP).

Poland, PL

Left:

Polska Zjednoczona Partia Robotnicza (PZPR), Polska Partia Pracy (PPP), Zjednoczone Stronnictwo Ludowe (ZSL).

Right:

Samoobrona Rzeczpospolitej Polskiej (SRP), Ruch Odbudowy Polski (ROP), Liga Polskich Rodzin (LPR), Prawo i Sprawiedliwość (piS), Kukiz'15 (Kukiz'15).

Portugal, PT

Left:

Bloco de Esquerda (BE), Partido Comunista dos Trabalhadores Portugueses/Movimento Reorganizativo do Partido do Proletariado (PCTP/MRPP), Coligação Democrática Unitária (CDU), União Democrática Popular (UDP), Partido Renovador Democrático (PRD).

Right: Portugal à Frente (PàF), CDS - Partido Popular (CDS-PP), Partido Nacional Renovador (PNR).

Romania, RO

Left:

Partidul Socialist al Muncii (PSM).

Right:

Partidul România Mare (PRM), Partidul Noua Generație - Creștin Democrat (PNGCD; früher Partidul Noua Generație, PNGCD/PNG), Partidul România Unită (PRU), Partidul Unităţii Naţionale a Românilor (PUNR).

Slovakia, SK

Left:

Right:

Komunistická strana Slovenska(KSS), Združenie robotníkov Slovenska (ZRS), Spoločná vol'ba. L'udová Strana Naše Slovensko (L'SNS), Slovenská národná strana (SNS), Pravá Slovenská národná strana (PSNS).

Slovenia, SI

Left:

Socialistična stranka Slovenije (SSS), Združena levica (ZL).

Right:

Slovenska Nacionalna Stranka (SNS), Lipa.

Sweden, SE

Left:

Vänsterpartiet (V).

Right: $\quad$ Sverigedemokraterna (SD), Ny Demokrati (NyD).

United Kingdom, UK

Left: $\quad$ Socialist Labour Party (SLP), Scottish Socialist Party (SSP).

Right: United Kingdom Independence Party (UKIP), Democratic Unionist Party (DUP), English Democrats Party (Eng Dem?), Scottish National Party (SNP). 